\title{
GC-MS Analysis of the Compositions and Antimicrobial Activities of Essential Oils From Five Species of Lamiaceae in Iran
}

mansureh ghavam ( $\square$ mansurehghavam@gmail.com )

University of Kashan

\section{Research Article}

Keywords: Lamiaceae, EOs, GC-MS, Antimicrobial activity, 1,8-Cineole.

Posted Date: August 26th, 2021

DOl: https://doi.org/10.21203/rs.3.rs-745421/v1

License: (9) (1) This work is licensed under a Creative Commons Attribution 4.0 International License. Read Full License 


\section{Abstract}

Essential oils (EOs) separated from Lamiaceae species attract more attention due to their abundant use in the preservation of natural foods and pharmaceutics and have gained considerable interester in research and industrial. The aim of this study was to evaluate composition and antimicrobial activity of EOs obtained from five species Lamiaceae in Iran. After extraction of EOs by Clevenger, their composition was evaluated by gas chromatography-mass spectrometry (GC-MS). Antimicrobial properties were assayed by measuring inhibition zones, minimum inhibitory concentration (MIC) and minimum bactericidal concentration (MBC). The results showed that the effects of species, on yield and predominant compounds amount of EOs of five species were significant with a probability of error of $1 \%$. The yield of oils were varied from $\sim 0.02$ to $~ 1.88 \%$. About 66 components were identified by gas chromatography-mass spectrometry (GC-MS), and the dominant compounds were included thymol (67.71\%), oleic acid (0.49-62.09\%), (-)-caryophyllene oxide (0.41-24.81\%), a-pinene (1.09$19.41 \%), 1,8$-cineole $(0.22-15.40 \%)$, palmitic acid $(0.32-13.28 \%),(+)$ spathulenol $(11.16 \%)$, and germacrene $\mathrm{D}(0.30-10.26 \%)$ in different species. The results of analysis of variance showed that there was a significant difference between the mean of the inhibition zone obtained treating the different microorganisms with the essential oil of five species $(P \leq 0.01)$. The highest inhibition zone belonged to TDEO (39.33 \pm 0.58 and $25.00 \pm 0.00 \mathrm{~mm}$ ) against Gram-positive $S$. aureus and $A$. brasiliensis. The Gram-negative $P$. aeruginosa showed the lowest inhibitory resistance to HIEO, SIEO, and ROEO (with a MIC value of $31.25 \mu \mathrm{g} / \mathrm{mL}$ ), which was very significant compared to rifampin. Therefore, EOs of five species have potential applications in the control of various bacteria and fungi and can be a natural alternative to some antibiotics.

\section{Introduction}

Due to the uncontrolled use of antibiotics, we have seen the emergence of multidrug-resistant bacterial and fungal strains that have become increasingly popular in recent decades to find new and safe antimicrobial molecules of natural origin, especially plant metabolites (Stojanović -Radić et al., 2018 and Mitić et al., 2018(. Against this worrying situation, other options must be developed to make natural, safe and effective antimicrobial drugs. Natural products, such as essential oils (EOs), have historically proven their value as sources of antimicrobial potential molecules and may have the potential for subsequent topical use or systemic administration in bacterial and fungal infections. Indeed, the synergistic interaction of EOs with antimicrobials has previously been reported to prevent multidrug resistance by restoring antimicrobial activity and preventing adverse antimicrobial side effects. (Fadli et al., 2012; Kasrati et al., 2014 and Ait sidi Brahim, 2015).

Lamiaceae EOs because of their interesting physicochemical characteristics of substantial value, have garnered research and industrial interests for use as natural products. These EOs mainly contain various phenolic compounds, such as monoterpene perillaldehyde, polyphenols, coumarins, tannins, iridoids, diterpenoids, triterpenoids, quinones, saponins, and pyridine and pyrrolidine alkaloids (El Asbahani et al., 2015). Studies have shown that many mint family plants such as thyme, peppermint, lavender, rosemary, peppermint, savory, marjoram have antimicrobial effects (Zargari, 2012 and Sekman et al., 2004).

Thymus daenensis Celak. is an Iranian herbaceous, that is distributed in most parts of Iran, especially throughout the Zagros and some parts of the Alborz Mountains (Jamzad, 2012; Zarshenas and Kern, 2015). Thymol, carvacrol, and p-cymene have been reported as the most important constituents in the EO of this plant (Sajjadi and Khatamsaz, 2003 Ghasemi Pirbalouti et al., 2013; Mehran et al., 2016 ; Nikavar and Mojab 2005; Askari and Sefidkon, 2003; Weisany et al., 2019 and Tohidi et al., 2017). In some studies, Thymol and $\beta$ caryophyllene were the dominant essential oil composition (Behbahani Hosseiniet et al., 2013). Antifungal and antibacterial effects of this plant (Ghasemi Pirbalouti et al., 2014 ; Safarpoor et al., 2018; Nematollahi et al., 2011; Hosseini Behbahani et al., 2013; Teimouri, 2012 and Moghimi et al., 2016) and therapeutic effects It has been proven for the treatment of asthma, recurrent dry cough and bronchitis (Nikavar and Mojab, 2004). It is also used as a food ingredient, herbal tea, and a medicinal plant because of its renowned therapeutic properties (Alizadeh et al. 2013).

Nepeta sessilifolia Bung is one of the exclusive species in Iran. It is a perennial shrubby plant a vital form of hemicryptophyte, often growing on the slopes of semi-arid mountains and rocky and rocky terrain (Batuli, 2002). The predominant essential oil constituents of this species are spathulenol (Talebi et al., 2019 and Safaei Ghomi et al., 2011) and some studies have reported linalool acetate and linalool (Jamzad et al., 2008). The antimicrobial activity of some Nepeta genera has been studied and proven (Formisano et al., 2011; Alim et al., 2009 and Ezzatzadeh et al., 2014).

Hymenocrater incanus Bunge is one of the exclusive species of this genus in Iran. The herbaceous plant is perennial with a wooden base 30 to $50 \mathrm{~cm}$ high (Jamzad, 2012). The major constituents of the EO of this plant have been reported as $\beta$-caryophyllene and 1,8-cineole, apinene, $\beta$-pinene, trans- $\beta$-ocimene, germacrene-D, and caryophyllene oxide (Mirza et al., 2001). Recent reports confirm the drug potential of the genus Hymenocrater for the development of new drugs. Plants of this genus have antibiotic, antifungal, antiparasitic, anti-cancer and 
anti-diabetic compounds that may be effective in the treatment of diseases (Alan et al., 2014, 2015 and Hooshyar et al., 2015). The antimicrobial properties of some species of this genus have been confirmed (Morteza-Semnani et al., 2010 and 2012 and Ahmadi et al., 2010).

Stachys inflate Benth. is a perennial plant at the base of a tree at a height of 15 to $40 \mathrm{~cm}$ (Khanvai et al., 2009). The aerial parts of this plant have been used as a herbal medicine in the treatment of infection, asthma, rheumatism and other inflammatory diseases (Alibakhshi et al., 2014 and Garjani et al., 2004). In most studies, germacrene-D, bicyclogermacrene, and a-pinene were the major constituents of the EO of this plant (Sajjadi and Somae, 2004; Morteza-Semnani et al., 2006; Meshkatalsadat et al., 2007 and Alibakhshi et al., 2014). The antimicrobial effects of the extract (Saeedi et al., 2008 and Rajabi et al., 2014) and the EO of this plant (Ebrahimabadi et al., 2009) have been reported.

Rosmarinus officinalis $\mathrm{L}$. The plant is in the form of durable small shrubs with aromatic leaves and small blue flowers (Inouye et al., 2001). Rosemary EO is one of the compounds that have antimicrobial and antioxidant properties in many cases and antimicrobial compounds such as phenolic compounds are found in abundance in it. Predominantly 1,8-cineole, camphor, (Pereira et al., 2017) a-pinene, borneol, and camphene (Ben Abada et al., 2020, Takayama et al., 2016; Tawfeeq et al., 2016 and Bajalan et al., 2017), have been reported as the major constituents of the EO of this plant. Antimicrobial effect of the extract (Oluwatuyi et al., 2004 and Yesil Celiktas et al., 2005) and EO (Bajalan et al., 2017; Messaoudi Moussi et al., 2019 and Risaliti et al., 2019), recorded. Rosemary EO is used in the treatment of indigestion and milder forms of gastrointestinal disorders, circulatory disorders, as a supplement in the treatment of musculoskeletal pain and inflammation (Rašković et al., 2014).

Studies on these species indicate the importance of these plants in terms of their essential oil composition and antimicrobial properties. However, no comprehensive study of these species has been performed simultaneously using Twelve strains of microorganisms. Since these plants have not been studied in the habitats of Isfahan province in Iran, this study is of particular importance. In particulary, most of the species studied are native to Iran. The aims of this study were 1) to determine the chemical composition of EOs of five species, and 2) to compare chemical compositions, yield variations and antimicrobial activities of EOs of 5 species.

\section{Materials And Methods}

\section{Plant material}

To select the sampling region, at first, habitats of plants (T. daenensis, N. sessilifolia, H. incanus, S. inflate, and R. officinalis) were identified

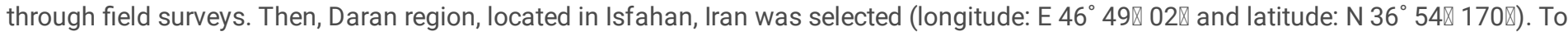
sample of each plant, in June 2018, coinciding with the flowering, three points were selected randomly from Daran region. In each point aerial parts of each plant randomly from different plants (50-100 plants in each point) were collected. The specimens were transferred to the laboratory after being harvested and then exposed to free air to dry. One sample of the whole plant was also collected and pressed. The specimens was identified and recorded in the herbarium of the University of Kashan

\section{Extraction of EOs}

After complete drying, the samples were grinded by using a small electric mill. Then from each sample of plant was weighed (100 g) and subjected to the extraction process by means of water distillation by using a Clevenger apparatus (Made in Germany) for five hours. The essential oil was dried by anhydrous sodium sulfate and after filtration, were stored in dark bottles at $4^{\circ} \mathrm{C}$ until their use for further studies. Essential oil yield was calculated based on weight percent $(\mathrm{w} / \mathrm{w})$. This process was repeated three times for each plant.

\section{Gas chromatography-mass spectrometry (GC-MS) analysis}

The main bioactives contained in the essential oils have been determined by means of GC-MS, using a chromatograph (Model 6890 Chromatography) coupled with an Agilent Mass Spectrometer (Model N-5973). A capillary column (HP-5MS) with 5\% Methylphenylsiloxane Static Phase (Length $30 \mathrm{~m}$, Internal Diameter $0.25 \mathrm{~mm}$, Layer Static Thickness $0.25 \mu \mathrm{m}$ ) and ionization energy of $70 \mathrm{eV}$ was used. The temperature for the analyses was first set at $60^{\circ} \mathrm{C}$ and then it was increased, at a rate of $3^{\circ} \mathrm{C}$ up to $246^{\circ} \mathrm{C}$. The injector and detector temperatures were maintained at $250^{\circ} \mathrm{C}$, the volume of the injected sample was $1 \mu \mathrm{l}$ and the helium carrier gas was maintained at a flow rate of $1.5 \mathrm{ml} / \mathrm{min}$. The identification of chemical components was based on the analysis of the chromatograms obtained for each oil, by means of the retention indices (RI) evaluation in comparison with standards of n-alkane mixtures (C8-C20) and mass spectral data of each peak by using a computer library (Wiley-14 and NIST-14 Mass Spectral Library), and comparison of the obtained results with those contained in the literature (Adams, 2007). 


\section{Tested microorganisms}

Twelve microorganisms, provided by the Iranian Research Organization for Science and Technology (IROST), have been used to evaluate the antimicrobial activity of the essential oils. Three Gram-positive bacteria Staphylococcus epidermidis (ATCC 12228), Staphylococcus aureus (ATCC 29737) and Bacillus subtilis (ATCC 6633) and nine Gram-negative bacteria Klebsiella pneumonia (ATCC 10031), Shigella dysenteriae (PTCC 1188), Pseudomonas aeruginosa (ATCC 27853), Salmonella paratyphi-A serotype (ATCC 5702), Proteus vulgaris (PTCC 1182) and Escherichia coli (ATCC 10536). Fungal strains were used as well Aspergillus niger (ATCC 16404), Aspergillus brasiliensis (PTCC 5011) and Candida albicans (ATCC 10231). Bacterial strains were cultured overnight at $37^{\circ} \mathrm{C}$ in nutrient agar and fungi were cultured overnight at $30^{\circ} \mathrm{C}$ in sabouraud dextrose agar.

\subsubsection{Agar diffusion method of Well diffusion}

This procedure was performed according to CLSI standards. $6.0 \mathrm{~mm}$ in diameter well plates containing Müller Hinton agar were prepared and $100 \mu \mathrm{l}$ of bacterial suspensions with a half-McFarland turbidity equivalent in culture medium were cultured. The essential oils were dissolved in dimethyl-sulfoxide (DMSO) at a concentration of $30 \mathrm{mg} / \mathrm{mL} .10 \mu \mathrm{L}$ (equivalent to $300 \mu \mathrm{g}$ ) of each oil was poured into the wells. The plates were incubated at $37^{\circ} \mathrm{C}$ for $24 \mathrm{~h}$ for bacterial strains and $48 \mathrm{~h}$ and $72 \mathrm{~h}$ at $30^{\circ} \mathrm{C}$ for yeast and its antimicrobial activity was evaluated for each microorganism by measuring the diameter of the inhibition halo (in millimeters), according to the antibiogram ruler. To evaluate the repeatability of the results, three replicates for each essential oils and each strain were performed. DMSO was used as negative control. Gentamicin (10 lg/disk), and rifampin ( $5 \mathrm{lg} /$ disk) for bacteria and nystatin (100 I.U.) for yeast were used as standard drugs for positive control in the same conditions to tested oils.

\section{Determine the Minimum inhibitory concentration (MIC)}

The minimum concentration able to inhibit the growth of bacteria was calculated by means of microdilution method. Essential oils (2000 $\mu \mathrm{g} / \mathrm{ml}$ ), were dissolved in a mixture of tryptic soy broth medium and DMSO and then were opportunely diluted, by using the same mixture, to reach different concentrations $(1000,500,250,125,62.5,31.25$ and $15.63 \mathrm{mg} / \mathrm{ml})$.

Sterile 96-well microplates were filled with $95 \mu \mathrm{l}$ of culture medium, $5 \mu$ l of bacterial suspension with $0.5 \mathrm{McFarland}$ dilution, and $100 \mu \mathrm{L}$ of the essential oils at different concentrations, then plates were incubated at $37^{\circ} \mathrm{C}$ for $24 \mathrm{~h}$ for bacterial strains and $48 \mathrm{~h}$ and at $30^{\circ} \mathrm{C}$ for yeast. The MIC was determined by means of the improvement of opacity or the change in color. The MIC was the lowest concentration of an antimicrobial that inhibited the visible growth (absence of turbidity).

\section{Determination of Minimum bactericide concentration (MBC)}

To determine the minimum concentration able to kill the bacteria the same microdilution method described above was used. After $24 \mathrm{~h}$ of incubation with both bacteria and oils at different concentrations, $5 \mu \mathrm{l}$ of the content of each well were inoculated with neutrin agar medium and incubated at $37^{\circ} \mathrm{C}$ for $24 \mathrm{~h}$ for bacterial strains. After incubation, the colony-forming units were enumerated. The MBC was the lowest concentration able to effectively reduce the growth of microorganisms (99.5\%).

\section{Statistical analysis}

The statistical analysis was performed using SPSS software. First, the normality of the statistical variables was investigated using a Kolmogorov-Smirnov test, and after ensuring the normality of the data, the variance of the data (essential oil and Antimicrobial activity) was analyzed using an F-test and a comparison of the means using a Duncan test with a probability level was $1 \%$ error was performed.

\section{Results}

\section{EOs content}

The EOs color varied from pale yellow to dark yellow with yields ranging from $1.88 \%-0.02 \%(\mathrm{w} / \mathrm{w})$. Based on the results of the analysis of variance, the yield of essential oil of five species was significantly different. The effect of the species on the yield of essential oil was significant ( $P \leq 0.01$ ) (Table 1), which is consistent with the findings of Luo et al., (2019) for Lamiaceae, Silva et al. (2018) for Myrtaceae, and Ngahang Kamte et al., (2018) for Apiaceae. The highest essential oil yield belonged to TDEO ( 1.88\%) and the lowest to HIEO $(\sim 0.02 \%)$ (Table 2 ). Essential oil yields can be greatly affected by environmental factors and plant species (Llorens et al., 2014). Compared to previous studies, the highest TDEO yields were 2.09\% (Tohidi et al., 2017), NSEO 0.56\% (Safaei Ghomi et al., 2011), HIEO 0.6\% (Mirza et 
al., 2001), SIEO. 2.9\% (Alibakhshi et al., 2014) and ROEO 2.35\% (Bajalan et al., 2017), that were larger than the present study. The synthesis of secondary compounds in plants is one of the most important defense mechanisms against pathogens, and its quantity varies depending on habitat, organ, species. These differences are most likely due to the differences in chemotyp, which are themselves due to the environmental conditions and climate (Yavari et al., 2010).

\section{GC-MS analysis}

The chemical constituents of EOs collected from five Lamiaceae species were investigated using GC-MS. About 68 components were identified and the relative composition of these five EOs, including TDEO (100\%), NSEO (84.56\%), HIEO (100\%) SIEO, (99.35\%) and ROEO (100\%) is presented in Table 3. Most of the compounds were monoterpenes hydrocarbons belonging to ROEO (39.55\%), oxygenated monoterpenes belonging to TDEO (74.9\%), sesquiterpenes hydrocarbons belonging to SIEO (26.25\%) and oxygenated sesquiterpenes belonging to HIEO (41.22\%). NSEO was mainly composed of non-terpene and acidic compounds (77.18\%).

Most of the compounds in TDEO were from oxygenated monoterpenes (74.9\%) and monoterpenes hydrocarbons (18.3\%).The predominant components in TDEO were thymol (67.71\%), y-terpinene (6.20\%), p-cymene (5.16\%) and borneol (3.67\%) and 1,8-cineole (15\%). (Table 3).

In NSEO, most of the compounds belonged to acids and mainly to non-terpenes (Table 3 ). The predominant components in the EO of this plant were oleic Acid (62.09\%), Stearic acid (8.16\%) and linoleic acid (6.06\%). These three compounds were first observed in this plant and so far no reports of these compounds have been reported even to a minor extent.

In HIEO, most of the compounds were acidic (50.65\%) and oxygenated sesquiterpenes (41.22\%) .Predominant components in HIEO were (-)caryophyllene oxide (24.81\%), oleic acid (23.53\%), palmitic acid (28.23\%), phytol (9.22\%), a-cadinol (7.66\%), and caryophyllenol-II (5.06\%), respectively (Table 3).

In SIEO, other compounds, especially acids (42.22\%) and sesquiterpenes hydrocarbons (26.25\%), were the major constituents of it, which is different from previous reports of this plant. Oleic acid (20.75\%), palmitic acid (12.12\%), (+)spathulenol (11.16\%), germacrene D (12.26\%) and bicyclogermacrene (9.9\%) are the main constituents of this EO (Table 3). In none of the previous reports has oleic acid been recorded so far.

In ROEO, mainly oxygenated monoterpenes (50.04\%) and monoterpenes hydrocarbons (39.55\%) comprised the major part of the essential oils, with findings by Pereira et al., (2017) and Takayama et al.(2016) corresponds. a-pinene (19.41\%), 1,8-cineole (15.40\%), camphor (8.87\%), borneol (8.48\%) and verbenone (8.8\%) were the major constituents of this EO (Table 3$)$.

Based on the results of analysis of variance the effect of the species on the amount of 1,8-cineole, oleic acid, (-)-caryophyllene oxide, transcaryophyllene and linalool was significant ( $\mathrm{P} \leq 0.01$ ) (Table 1). The data presented in Table 1 show that 1,8-cineole and oleic Aacid were found in the essential oils of 5 plant species. The highest amount of 1,8-Cineole was observed in ROEO with $15.40 \%$ and the lowest with $0.22 \%$ in HIEO (Figure 1). The highest and lowest amount of oleic acid was in NSEO (62.09\%) and TDEO (0.49\%), respectively (Figure 2). Linalool was found in all essential oils except HIEO, with the highest amount being $2.97 \%$ in ROEO. Also, trans-caryophyllene and (-)caryophyllene oxide were found in all essential oils except SIEO with the highest amount being $3.68 \%$ and $24.81 \%$ in HIEO, respectively. Some high-value compounds such as thymol (67.71) and p-cymene (5.16), only in TDEO, linoleic acid (6.06) only in NSEO, caryophyllenol-II (5.06) only in HIEO, (+) spathulenol (11.16) only in SIEO and $\beta$-myrcene (5.38) existed only in ROEO.

\section{Antimicrobial activity}

\section{Inhibition-zone}

The results of analysis of variance showed that there was a significant difference between the mean of the inhibition halo obtained treating the different microorganisms with the essential oil of five Lamiaceae species (P $\leq 0.01)$ (Table 4). Similar trend was observed by Luo et al., (2019) for six other species of lamiaceae. The highest inhibition zone was belonged to TDEO (39.33 $\pm 0.58 \mathrm{~mm})$ against Gram-positive $S$. aureus compared to the inhibition zone rifampin $(\sim 21 \mathrm{~mm})$ and gentamicin $(\sim 27 \mathrm{~mm})$ is a significant activity (Table 5). Other essential oils such as NSEO $(9.67 \pm 0.58 \mathrm{~mm})$, SIEO $(8.50 \pm 0.50 \mathrm{~mm})$ and ROEO $(9.00 \pm 0.00 \mathrm{~mm})$ had little activity on this bacterium and HIEO did not produce any diameter. Reduction of monoterpenes in HIEO seems to be one of the factors affecting the lack of inhibition halo against this S. aureus. In addition, this antibacterial activity of TDEO, NSEO, SIEO, and ROEO can be attributed to other oxygenated compounds such as linalool.

Secondly, was the highest inhibition zone $(25.00 \pm 0.00 \mathrm{~mm})$, belonging to TDEO against $A$. brasiliensis, which is a significant activity compared to the Nystatin $(\sim 30 \mathrm{~mm})$ control antibiotic growth zone against $A$. brasiliensis (Table 5). On the other hand, the effect of TDEO

Page 5/21 
on the fungi $A$. sniger and $C$. albicans also caused an inhibition zone diameter of $12.00 \pm 0.00 \mathrm{~mm}$ and $11.67 \pm 0.58 \mathrm{~mm}$, respectively, in comparison with the inhibition zone of Nystatin control antibiotic ( 27 and $\sim 33 \mathrm{~mm}$ ), had low activity on these fungi.

On the other hand, TDEO with inhibition zone diameter of $17.67 \pm 0.58 \mathrm{~mm}$ and $16.33 \pm 0.58 \mathrm{~mm}$ against two Gram-negative bacteria $K$. pneumonia and Sh. dysenteriae showed good activity in comparison with inhibition zone of antibiotic rifampin ( 8 $\mathrm{mm}$ and $\sim 9 \mathrm{~mm})$ and antibiotic control gentamicin $(\sim 17 \mathrm{~mm})$. so far no report of the effect of TDEO on these two bacteria has been reported and therefore, the present study is important. Also TDEO against $B$. subtilis and $P$. vulgaris had a low activity, with inhibition zone diameter of $14.00 \pm 0.50$ mm compared to inhibition zone rifampin ( 19 and $\sim 8 \mathrm{~mm})$ and gentamicin ( 30 and $\sim 24 \mathrm{~mm})$.

TDEO also had little effect against two Gram-negative bacteria $E$. coli and $S$. paratyphi-A with inhibition zone $11.33 \pm 0.58$ and $11.67 \pm 0.58$ $\mathrm{mm}$, respectively, compared to inhibition zone diameter rifampin ( 10 and $\sim 8 \mathrm{~mm})$ and gentamicin ( 23 and $\sim 18 \mathrm{~mm})$ low effect is quite obvious.

Inhibition zone of NSEO was only present against three Gram-positive B. subtilis, S.epidermidis ( $9.00 \pm 0.00 \mathrm{~mm})$, and S. aureus (9.67 \pm 0.58 $\mathrm{mm}$ ), which had little activity compared to rifampin and gentamicin. The NSEO did not create inhibition zone against other

microorganisms.

Inhibition zone of HIEO was created only against two Gram-positive bacteria, B. subtilis (10.00 \pm 0.00 and S.epidermidis (11.00 \pm 0.00 mm), which had little activity compared to rifampin and gentamicin. HIEO did not create inhibition zone against other microorganisms. The SIEO was exhibited little activity against Gram-positive bacteria B. subtilis (inhibition zone diameter $9.00 \pm 0.00 \mathrm{~mm}$ ) and $S$. aureus (inhibition zone diameter $8.50 \pm 0.50 \mathrm{~mm}$ ). The present results are remarkable when compared to the report of Ebrahimabadi et al., (2009), for the lack of SIEO inhibition zone diameter against these micro-organisms. Inhibition zone diameter of ROEO against three gram-positive bacteria $B$. subtilis, $S$. aureus $(9.00 \pm 0.00 \mathrm{~mm})$ and $S$. epidermidis $(9.33 \pm 0.58 \mathrm{~mm})$, which had little activity compared to control antibiotics rifampin and gentamicin.

\section{Minimal inhibitory concentrations (MIC)}

The values of MIC varied from 15.63> $\mu \mathrm{g} / \mathrm{mL}$ to $>2000$ as a function of the organism tested and the used oil (Table 6 ). The lowest inhibitory concentration was found against $P$. aeruginosa (MIC $=31.25 \mu \mathrm{g} / \mathrm{mL}$ ) by HIEO, SIEO, and ROEO, which was very significant compared to rifampin $(\sim 31.25 \mu \mathrm{g} / \mathrm{mL})$ and gentamicin $(\sim 7.81 \mu \mathrm{g} / \mathrm{mL})$. It has been previously reported that $P$. aeruginosa is highly sensitive to EOs (De Martino et al., 2009). Other EOs with a MIC value of $125 \mu \mathrm{g} / \mathrm{mL}$ had a much weaker inhibitory effect against $P$. aeruginosa. All EOs (except TDEO) with MIC value of $2000 \mu \mathrm{g} / \mathrm{mL}$ showed the highest resistance to A. brasiliensis and A. niger. On the other hand, SIEO with a MIC value of $>1000 \mu \mathrm{g} / \mathrm{mL}$ showed the highest resistance to $S$. aureus, which was two to four times weaker than other EOs studied.

The MIC value of TDEO against all the different bacteria varied between 125 and $500 \mu \mathrm{g} / \mathrm{mL}$, with its weakest inhibitory effect against Sh. dysenteriae in compared with rifampin (MIC $=15.63 \mu \mathrm{g} / \mathrm{mL}$ ) and gentamicin (MIC =3.90 $\mu \mathrm{g} / \mathrm{mL})$, which contradicts the results of Golkar et al. (2020) for TDEO. The MIC value of TDEO against all fungi varied from 31.25 to $250 \mu \mathrm{g} / \mathrm{mL}$. $C$. albicans showed the least inhibitory resistance to TDEO among all microorganisms, which is significantly more potent and three times more potent than nystatin ( $125 \mu \mathrm{g} / \mathrm{mL})$. C. albicans is one of the most common pathogenic fungi in nature that causes serial infectious diseases and has become a serious threat to human health. The MBC value of TDEO also varied from $62.50 \mu \mathrm{g} / \mathrm{mL}$ to $500 \mu \mathrm{g} / \mathrm{mL}$ (Table 4). The results indicate that the MBC value of TDEO on all microorganisms (except S. aureus, K. pneumonia, and C. albicans) was always equal to the MIC value (Table 6 and 7 ), indicating that growth and lethal inhibitory power of TDEO are the same.

The MIC value of NSEO against all microorganisms varied between 125 and $2000 \mu \mathrm{g} / \mathrm{mL}$. Its strongest inhibitory effect was against Gramnegative bacteria Sh. dysenteriae, K. pneumonia and $P$. aeruginosa, that it is three to four times weaker than control antibiotics. The weakest inhibitory effect of this essential oil was against $A$. sniger and $A$. brasiliensis. The results showed that the MBC value of NSEO was the same as MIC value of NSEO in all microorganisms (except $S$. aureus, B. subtilis, Sh. dysenteriae, and $P$. vulgaris). This indicates that NSEO's growth and lethal inhibitory potency against many of microorganisms is the same. The lowest MBC value of NSEO belonged to Sh. dysenteriae and K. pneumonia, which was equivalent to MIC value of NSEO, confirming the importance of this EO in inhibiting and killing Sh. dysenteriae and K. pneumonia. The absence of terpenes predominantly in the EO of this plant may be due to its poor antimicrobial effect, although the relatively weak effect of NSEO on some bacteria may be due to the presence of fatty acids (Oleic acid 62.09\%). However, the mechanism of the antibacterial activity of fatty acids is not yet known. But it is believed that their functional nature is related to the permeability and membrane disruption and fatal alterations in the cytoplasmic membrane of the bacterium, thereby disrupting the membrane-dependent conduction systems. 
The MIC value of HIEO was against all microorganisms varied between $15.63>->2000 \mu \mathrm{g} / \mathrm{mL}$. The strongest inhibitory effect was against Gram-negative $P$. aeruginosa (MIC $15.63>\mu \mathrm{g} / \mathrm{mL}$ ), which is very significant in comparison with rifampin $(\mathrm{MIC}=31.25 \mu \mathrm{g} / \mathrm{mL}$ ). HIEO had a good effect against Sh. dysenteriae, K. pneumonia, and S. paratyphi-A with MIC value of HIEO $62.50 \mu \mathrm{g} / \mathrm{mL}$ (compared with rifampin MIC value of $15.63 \mu \mathrm{g} / \mathrm{mL}$ against Sh. dysenteriae, K. pneumonia, and S. paratyphi-A), that was consistent with results of Fazly Bazzaz and Haririzadeh, (2003) for $H$. calycinus. Also the MIC value of HIEO against $C$. albicans was $62.50 \mu \mathrm{g} / \mathrm{mL}$, which was weaker than nystatin $(\mathrm{MIC}=125 \mu \mathrm{g} / \mathrm{mL}$ ). This is evident in the results of the MBC value of HIEO and the lethality of this against $C$. albicans has been increased to $250 \mu \mathrm{g} / \mathrm{mL}$.

Also the MIC value of SIEO was against all microorganisms varied between $15.63>->2000 \mu \mathrm{g} / \mathrm{mL}$, that the strongest inhibitory effect was against the Gram-negative bacterium $P$. aeruginosa. ROEO had the strongest inhibitory effect against $P$. aeruginosa (with MIC value 15.63> $\mu \mathrm{g} / \mathrm{mL}$ ), which was twice as potent as the MIC value of rifampin.

\section{Discussion}

Similarly, a difference in the relative composition of the essential oils of different species of the Lamiaceaefamily by Luo et al., (2019) and species of the Apiaceae family by Ngahang Kamte et al., (2018) has been observed. The production and accumulation of metabolites in individuals with a similar species that are growing in different regions may be influenced by environmental factors, such substances appear to play a chemical interface between the plant and the environment (Gutbrodtet et al., 2012). Environmental factors (eg, average temperature, precipitation, and longitude) are likely to play a role in the selection of specialized genotypes/chemotypes for monoterpenes that lead to different chemistry (Taft et al., 2015).

In almost all studies on this plant, thymol had the highest percentage of essential oil with diffrent amount, that the highest amount of thymol by Weisany et al., (2019) from Kurdistan region of Iran (91.15\%) observed. Similarly, differences in the proportion of constituent components of essential oils between samples of one plant from different geographical areas, particularly the predominant composition, have been observed by Lukas et al., (2009) for Origanum syr-iacum L., and by Sampaio and Batista (2017) for Tithonia diversifolia (Hemsl.) A.Gray species. These data from literature indicatethat the surrounding environment seems to significantly influencethe production and accumulation of volatile constituents in aerialparts of T. daenensis. Due to the high percentage of thymol, this species can be considered as the main base of this valuable compound. Numerous studies have shown that thymol is one of the phenolic compounds that have been shown to have very effective antimicrobial and antimicrobial properties in EOs (Villanueva-Bermejo et al., 2015; Gavaric et al., 2015 and Ultee et al., 1999).

As reported in Safaei Ghomi et al., (2019) and Talebi et al., (2011), oxygenated sesquiterpene (35.3\% and 33.14\%), and in the study of Jamzad et al. (2008), oxygenated monoterpene (49\%) contained the highest percentage of EO compounds of this species, which did not correspond to the present results.

The yields and effects of medicinal plants vary depending on the locations of growth, climatic and ecological conditions, field operations, growth stages, and genetic traits (Millauskas et al., 2004). Oleic acid (9-octadecenoic acid) is a component of omega-9 fatty acids. This fatty acid is effective in treating cancer and cardiovascular disease, autoimmune diseases, Parkinson's, Alzheimer's, inflammatory diseases and high blood pressure. Its derivatives have a regulatory role on the cell membrane and are used as an anticancer drug that induces cell apoptosis and cell division (Sales-Campos et al., 2013; Choque et al., 2014 and Gonçalves et al., 2014). Linoleic acid is one of the most abundant unsaturated fatty acids in the human diet, which is one of the omega- 6 fatty acids and plays an active role in the growth and general health of the human body (Sales-Campos et al., 2013).

Although some common compounds in the present study were similar to the results of Mirza et al., (2001); however, there was a significant difference between the two studies. In particular, none of the major constituents of the essential oil present, was recorded in Mirza et al., (2001). These differences are most likely due to the chemotypic differences that result from the environmental and climate conditions of the studied habitats (Yavari et al., 2010). Caryophyllene oxid inhibits abnormal accumulation of fluid in the intercellular space of body tissues and antitumor (Jaimand and Rezaei, 2006).

Palmitic acid as the predominant compound with amount 9.1\% have recorded by Morteza-Semnani et al., (2006). Germacrene D and bicyclogermacrene by Morteza-Semnani et al., (2006) $8.9 \%$ and 5.1\%, by Sajjadi and Somae, (2004) $16.9 \%$ and $16.6 \%$, and by Meshkatalsadat et al., (2007) $32.9 \%$ and $7.3 \%$ was reported. Differences in the types and percentages of constituents may be due to genetic or non-genetic variations in response to environmental differences such as soil chemical composition and physiographic factors and or quantity of plant material (Zuzarte and Salgueiro, 2015) or various growth stages of the collected species (Ghasemi Pirbalouti et al., 2013), 
and or different methods for the extraction of EOs (Hashemi et al., 2010). Germacrene are a class of volatile organic hydrocarbons, in particular terpenes. Germacrene in some plant species possess antimicrobial and insecticidal properties (Telascrea et al., 2007).

Basically in all previous reports, 1,8-cineole with a content of 48.72\% (Risaliti et al., 2019), 37.06\% (Moussi et al., 2019), 32.90\% (Pereira et al., 2017), 57.88\% (BenAbada et al., 2020), and 26.89\% (Bajalan et al., 2017) had the highest percentage of EO of this species and also Camphor with 11.72\% (Risaliti et al., 2019),11.81\% (Pereira et al., 2017), 18.99\% (BenAbada et al., 2020 ), and 24.82\% (Bajalan et al., 2017) was the second main compound in previous reports. a-pinene, which accounted for the most in the present study, in previous reports with a content of 9.86\% (Risaliti et al., 2019), 10.71\% (Pereira et al., 2017), 9.18\% (BenAbada et al., 2020), and 20.81\% (Bajalan 2017), was the third major constituent of essential oils. These results indicate that the essential oils of these five Lamiaceae species can be considered as economically viable natural sources for this various high-value compounds. Similar trend was observed by Luo et al., (2019) for six species of lamiaceae.

Thymol is a highly effective phenolic and antimicrobial compound in TDEO. Thymol, as the most important phenol present in plant essential oils, is an inexpensive antibacterial source and can be used in pathogenic systems (Nejad Ebrahimi et al., 2008). The antimicrobial effect of thiol is due to permeability of cell membranes, which can be clotted with membrane surface cations and disrupt vital activities (Ultee et al., 1999). Similar results have been obtained by Wetwitayaklung et al. (2009) for Aquilaria crassna L. extract against S. aureus due to the presence of some compounds. The antimicrobial effect of essential oils is not limited to their major ingredients. In fact, it is possible that compounds with a lower percentage are likely to have a synergistic effect with otheractive compounds (Khajehie et al., 2017 and Naeini et al., 2009).

TDEO contained high Thymol, and extensive research has shown that Thymol exhibits good antifungal activity against a wide range of plant pathogenic fungi and food contaminants (Villanueva-Bermejo et al., 2015 and Gavaric et al., 2015). The mechanism of action of these compounds has not been fully elucidated, but it is believed that can interfere with or damage the cell wall of the fungi, or cause their cell wall to decay (Isman and Machial, 2006). Which is inconsistent with findings Hosseini Behbahani et al., (2013) for effect of TDEO against A. sniger and C. albicans ( $\sim 53.7$ and $\sim 37.7 \mathrm{~mm})$ and Dadashpour et al., (2011) for effect of TDEO against $C$. albicans $(\sim 63 \mathrm{~mm})$. While no one of the EOs of the other four species did not produced any inhibition zone (ND) on A. brasiliensis, A. sniger, and C. albicans (Table 5).

But Hosseini Behbahani et al., (2013) reported a remarkable effect of TDEO (43 mm) against $B$. subtilis, which contradicts the present study. This effect may be related to monoterpene and phenolic compounds that are able to break down the outer membrane of Gramnegative strains (Callo et al., 2015).

In previous reports, the effect of TDEO against E. coli was $\sim 7 \mathrm{~mm}$ (GhasemiPirbalouti et al., 2010), 7.1 mm (Golkar et al. 2020), 27.7 $\mathrm{mm}$ (Hosseini Behbahani et al., 2013), and $\sim 43.67 \mathrm{~mm}$ (Dadashpour et al., 2011). Inhibition zone TDEO was recorded against Gram-positive $S$. epidermidis with $9.00 \pm 0.001$. However, there is no reported effect of this EO on S. paratyphi-A and S. epidermidis. The difference of antimicrobial activities between species from the same genus might be due to the difference of their major compounds and also to the complexity of EOs chemical profiles. In the present study EOs against $P$. aeruginosa did not produce any inhibition zone. The reverse process has been developed by Luo et al., (2019) for six species of lamiaceae against $P$. aeruginosa, so that ROEO has created the highest inhibition zone against this bacterium. This difference in antibacterial activity can be due to the difference in the composition of the essential oil of this species in different regions. The biological activities of the essential oils depend on chemical constituents (PopovićDjordjević et al., 2019).

These results are inconsistent with the findings of Ezzatzadeh et al., (2014) for Nepeta asterotricha. Since the major constituents of NSEO were, oleic acid, stearic acid, and linoleic acid, one might argue that the microbial effect is due to these fatty acids. Fatty acids have antifungal and antibacterial activities against many microorganisms whose spectrum of activity varies based on the degree of saturation, the length of the carbon chain and the orientation of the double bond (Mattanna et al., 2014). Studies have shown that Lauric, palmitic and linolenic have potential antibacterial activity against S. aureus (McGaw et al., 2002 and Agoramoorthy et al., 2007). There are no reports of antimicrobial activity of this plant so far and these results are important.

It may be explained by different composition and percentage of active compounds in EOs, variation in subtypes of genotypes, drying and extraction methods that appear to have a significant effect on the capacity to slow down or stop the growth of bacteria or kill them. (Mohsenipour and Hassanshahaian, 2015). ROEO did not create a diameter against other microorganisms, which is in some cases consistent with the results of Risaliti et al., (2019).

Essential oils of different specie due to the large number of chemical compounds, which work simultaneously, have unparalleled antibacterial potentials and prevent bacterial resistance mechanisms. In addition, synergistic interactions between EOs can enhance their natural antimicrobial effect. Therefore, antimicrobial potential cannot be associated with a single component or mechanism of action 
(Candy et al., 2018). Meanwhile, antibiotic abuse exacerbates the harm of $C$. albicans (Delcour, 2009). So TDEO as a natural alternative against this fungus has significant and promising potential. The presence of phenolic monoterpenes, and especially p-cymene and Thymol, is a major cause of the strong antifungal activity of TDEO. Phenolic compounds have high antimicrobial properties and in fact, phenolic compounds in plant essential oils have the most effect on the development of the antimicrobial activity (Lemos et al., 2017; Mahboubi et al., 2017). These compounds both penetrate the cell membrane and can contribute to the clotting of cell contents (Burl \& Coote 1999 and Dorman \& Dean 2000). Also, although a-pinene is present in small amounts in TDEO ( 1.09\%), it can be another factor influencing this antifungal activity. Research shows the antifungal effect of this compound (Dorman, 2000). In general, the synergistic effects of the diversity between the main and minor components of essential oils in their biological and antimicrobial activity should be considered (Raut and Karuppayil, 2014). The lowest MBC value of TDEO has belonged to $C$. albicans, that was consistent with results of Dadashpour et al., (2011).

Similar findings was observed by Morteza- Semnani et al. (2010) for $H$. elegans and Ahmadi et al. (2010) for H. longiflorus is consistent with. But MBC value of HIEO in other microorganisms was always equal to MIC value of HIEO. This results demonstrates the remarkable inhibitory and lethal potency of this EO against most bacteria. The higher amount of oxygenated sesquiterpenes compounds such as (-)Caryophyllene oxide ( $24.81 \%)$ and a-Cadinol $(\sim 7.66 \%)$ in HIEO compared to other essential oils can be one of the factors affecting this antimicrobial activity. similarly, Ali et al., (2017) observed that essnetial oil of Teucrium spicastrum Hedge \& A.G.Mill. (Lamiaceae) characterized by the abundance of $\mathrm{\gamma}$-selinene presented important antimicrobial activities against several micro-organisms.

In the study of Ebrahimabadi et I., (2009), SIEO had no inhibitory effect on any of the microorganisms, so the plant sample of this study is valuable. Differences in habitat conditions are among the most important causes of these biological traits in the plant, which has led to the dominance of acidic compounds and Sesquiterpenes, followed by the ability of this essential oil to control some bacteria. The HIEO MBC value against various bacteria (except $S$. epidermidis and $S$. aureus) was always higher than its MIC value, indicating that the lethal potency of this essential oil was lower than its inhibitory potency. Another report showed that aqueous extract from Aquilaria crassna (Wetwitayaklung et al., 2009) rich of the some sesquiterpene compound was active against some microorganisms.

Some differences in the amount of antimicrobial effects observed in this study and similar studies could be due to differences in the growth locations of the EO producing plants, the use of different methods for extraction, harvesting time and even the concentration of EOs (HasSzymanczuk et al., 2011; Lopez et al., 2005 and Toyoshi et al., 2006). Differences in antimicrobial effects indicated differences in essential oil composition. The ROEO also showed a good inhibitory effect $(31.25 \mu \mathrm{g} / \mathrm{mL})$ against Sh. dysenteriae, E. coli and K. pneumonia, which was weaker than control antibiotics. The lowest MIC value of ROEO was recorded against fungi. The MBC value against the associated microorganisms was also higher than the MIC value, indicating a lower lethal force than the inhibitory power, which is consistent with the results of Messaoudi Moussi et al. (2019). The major compounds that have been attributed to the antimicrobial properties of ROEO include a-pinene, 1,8-cineole, verbenone, and linalool (Okoh, 2010 and Oluwatuyi et al., 2004), among these compounds, three conditions may occur: Synergetic, Antagonist, and Additive. Occurrence of any of these conditions affects the antimicrobial properties of essential oil (Marzouk et al., 2006). There is ample evidence that the essential compounds of essential oils also play an important role in antimicrobial properties by creating a synergistic effect between the main compounds and their easier transfer into the bacterial cell (Burt, 2004 and Tavassoli et al., 2011).

Essential oils (EOs) produced by plants as secondary metabolites, usually composed of different compounds with different ratios. The present study was conducted for the first time on five important species of the Lamiaceae family in Iran which after analysis by chromatography included a variety of compounds such as thymol, oleic acid, (-)-caryophyllene oxide, a-pinene, 1,8-cineole, palmitic acid, $(+)$ spathulenol, germacrene D, bicyclogermacrene, phytol, camphor, and borneol. 1,8-cineole and oleic acid were found in the EOs of five plant species. The diversity of compounds of different species resulted in a variety of antibacterial and antifungal activity. TDEO had the highest inhibitory zone against various microorganisms compared to other essential oils, which had a particularly significant effect against $S$. aureus and A. brasiliensis. Based on the MIC value results, essentail oils of five species of Lamiaceae had a relatively good effect against Sh. dysenteriae, P. aeruginosa, E. coli, K. pneumonia, C. albicans. Overall, the MIC value of ROEO against all bacteria was significantly more effective than other EOs. These essential oils from five species of Lamiaceae can have potential applications in the food and pharmaceutical industries as natural food preservatives, natural fungicides and a potential natural alternative to some antibiotics. In future research, it is important to identify and separate the main components or general compounds of these essential oils to confirm the usefulness of these compounds.

\section{Declarations}

\section{Ethical Approval}

Page $9 / 21$ 
Not applicable.

\section{Consent to Participate}

Not applicable.

\section{Consent to Publish}

Not applicable.

\section{Authors Contributions}

Mansureh Ghavam was the supervisor, designer of the hypotheses, and responsible and functor for all the steps and wrote the text of the article.

\section{Funding}

No funding

\section{Competing interests}

The authors declare no competing interests.

\section{Availability of data and material}

Not applicable.

Acknowledgements

Not applicable

\section{References}

1. Agoramoorthy, G., Chandrasekaran, M., Venkatesalu, V., Hsu, M., 2007. Antibacterial and antifungal activities of fatty acid methyl esters of the blind-your-eye mangrove from India. BJM 38, 739-742.

2. Ahmadi F, Sadeghi S, Modarresi M, Abiri R, Mikaeli A. 2010. Chemical composition,in vitro anti-microbial, antifungal and antioxidant activities of the essential oil and methanolic extract of Hymenocrater longiflorus Benth., of Iran. Food Chem Toxicol. 48:1137-1144.

3. Ait sidi Brahim, M., Fadli, M., Hassani, L., Boulay, B., Markouk, M., Bekkouche, K., Abbad, A., Ait ali, M., Larhsini, M., 2015. Chenopodium ambrosioides var. ambrosioides used in Moroccan traditional medicine can enhance the antimicrobial activity of conventional antibiotics. Ind. Crop. Prod. 71, 37-43. https://doi.org/10.1016/j.indcrop.2015.03.067.

4. Ali, N., Chhetri, B., Dosoky, N., Shari, K., Al-Fahad, A., Wessjohann, L., Setzer, W., 2017. Antimicrobial, antioxidant, and cytotoxic activities of Ocimum forskolei and Teucrium yemense (Lamiaceae) essential oils. Medicines 4 (17), 1-14.

5. Alibakhshi, M., Mahdavi, S. Kh., Mahmoudi, J., Gholichnia, H. 2014. Phytochemical study of essential oil of Stachys inflata in different habitats of Mazandaran province. Eco-phytochemical Journal of Medicinal Plants, 2(2):56-68.

6. Alim, A., Goze, I., Cetin, A., Atas, A.D., Cetinus, S.A., Vural, N., 2009. Chemical composition and in vitro antimicrobial and antioxidant activities of the essential oil of Nepeta nuda L. subsp albiflora (Boiss.) gams. Afr. J. Microbiol. Res. 3, 463-467.

7. Alizadeh, A., Alizadeh, O., Amari, G., \& Zare, M. (2013). Essential oil composition, total phenolic content, antioxidant activity and antifungal properties of Iranian Thymus daenensis subsp. daenensis Celak. as in influenced by ontogenetical variation. Journal of Essential Oil Bearing Plants, 16(1), 59-70.

8. Askari, F., Sefidkon, F., 2003. Essential oil composition of Thymus daenensis Celak. from Iran. J Essent Oil Bearing Plants. 6, $217-219$.

9. Bajalan, I., Rouzbahani, R., Pirbalouti, A.G., Maggi, F., 2017. Antioxidant and antibacterial activities of the essential oils obtained from seven Iranian populations of Rosmarinus officinalis. Ind. Crops Prod. 107, 305-311.

10. BenAbada, M., Haouel Hamdib, S., Masseoudc, C., Jroudd, H. Bousshihb, E., Mediouni Ben Jemaab, J. 2020. Variations in chemotypes patterns of Tunisian Rosmarinus officinalis essential oils and applications for controlling the date moth Ectomyelois ceratoniae (Pyralidae). South African Journal of Botany, 128:18-27. 
11. Burt, S, 2004. Essential oils: their antibacterial properties and potential application in foods - A review. International Journal of Food Microbiology, 94:223-53.

12. Calo, J.R., Crandall, P.G., O'Bryan, C.A., Ricke, S.C., 2015. Essential oils as antimicrobials in food systems - a review. Food Control 54, 111-119.

13. Candy, K., Nicolas, P., Andriantsoanirina, V., Izri, A., Durand, R., 2018. In vitro efficacy of five essential oils against Pediculus humanus capitis. Parasitol. Res. 117, 603-609.

14. Choque, B., Catherine, D., Rioux, V., and Legrand, P. 2014. Linoleic acid: Between doubts and certainties. Biochimie. 96: $14-21$.

15. Dadashpour, M., Rasooli, I., Sorouri Zanjani, R., Sefidkon, F., Taghizadeh, M., Darvish Alipour Astaneh, S. 2011. Antimicrobial, nitric oxide radical scavenging and cytotoxic properties of Thymus daenensis essential oil. MJMS. 14 (1) :37-47.

16. De Martino, L., De Feo, V., Nazzaro, F., 2009. Chemical composition and in vitro antimicrobial and mutagenic activities of seven Lamiaceae essential oils. Molecules 14 (10), 4213-4230.

17. Delcour, A.H., 2009. Outer membrane permeability and antibiotic resistance. Biochim. Biophys. Acta 1794, 808-816.

18. Dorman, HJD., Deans, SG.2000, Antimicrobial agents from plants: antibacterial activity of plant volatile oils. J Appl Microbiol 88:308316.

19. Dufour M, Manson JM, Bremer PJ, Dufour JP, Cook GM, Simmonds RS. Characterization of monolaurin resistance in Enterococcus faecalis. Appl Environ Microbio 2007 ;51: 55075515.

20. Ebrahimabadi, A., Ebrahimabadia, E., Jafari-Bidgolia, Z., JookarKashia, F. Mazoochi, A. and Batooli, Hossein. 2010. Composition and antioxidant and antimicrobial activity of the essential oil and extracts of Stachys inflata Benth from Iran. Food Chemistry, 119(2): 452458.

21. El Asbahani, A., Miladi, K., Badri, W., Sala, M., Ait Addi, E.H., Casabianca, H., El Mousadik, A., Hartmann, D., Jilale, A., Renaud, F.N., Elaissari, A., 2015. Essential oils: from extraction to encapsulation. Int. J. Pharm. 483, 220-243.

22. Ezzatzadeh, E., Fallah Iri Sofla, S., Pourghasem, E., Rustaiyan, A. and Zarezadeh, A. (2014) Antimicrobial Activity and Chemical Constituents of the Essential Oils from Root, Leaf and Aerial Part of Nepeta asterotricha from Iran, Journal of Essential Oil Bearing Plants, 17:3, 415-421

23. Fadli, M., Saad, A., Sayadi, S., Chevalier, J., Mezrioui, N., Pagès, J., Hassani, L., 2012. Antibacterial activity of Thymus maroccanus and Thymus broussonetii essential oils against nosocomial infection - bacteria and their synergistic potential with antibiotics. Phytomedicine 19, 464-471. https://doi.org/10.1016/j.phymed.2011.12.003.

24. Fazly Bazzaz BS, Haririzadeh G. 2003. Screening of Iranian plants for antimicrobial activity. Pharm Biol. 41:573-583.

25. Formisano, C., Rigano, D., Senatore, F., 2011. Chemical constituents and biological activities of Nepeta species. Chem. Biodivers. 8, 1783-1818.

26. Garjani, A., Maleki, N., Nazemiyeh, H. 2004. Effects of hydroalcoholic extract from aerial parts of the sterile stems of Stachys inflata on myocardial infarct size in rats. Iranian Journal of Pharmaceutical Research 3(3): 165- 170.

27. Gavaric, N., Mozina, S. S., Kladar, N. and Bozin, B. 2015. Chemical profile, antioxidant and antibacterial activity of Thyme and Oregano essential oils, Thymol and Carvacrol and their possible synergism. Journal of Essential Oil Bearing Plants. 18(4): $1013-1021$.

28. Ghasemi Pirbalouti, A., Jahanbazi, P., Enteshari, S., Malekpoor, F., Hamedi, B., 2010. Antimicrobial activity of some Iranian medicinal plants. Arch. Biol. Sci. 62, 633-641.

29. Ghasemi Pirbalouti, A., Barani, M., Hamedi, B., Ataei Kachouei, M., Karimi, A., 2013. Environment effect on diversity in quality and quantity of essential oil of different wild populations of Kerman thyme. Genetika 45, 441-450.

30. Ghasemi Pirbalouti, A., Samani, M., Hashemi, M., Zeinali, H., 2014. Salicylic acid affects growth, essential oil and chemical compositions of thyme (Thymus daenensis Celak.) under reduced irrigation. Plant Growth Regul. 72, $289-301$.

31. Golkara, P., Mosavata, N. and Hossein Jalali S. A. 2020. Essential oils, chemical constituents, antioxidant, antibacterial and in vitro cytotoxic activity of different Thymus species and Zataria multiflora collected from Iran. South African Journal of Botany. 130: 250258.

32. Gonçalves, F.A.G., Colen, G., and Takahashi, J.A. 2014. Yarrowia lipolytica and its multiple applications in the biotechnological industry. The Scientific World. J. 1-14.

33. Gutbrodt, B., Dorn, S., Unsicker, S.B., Mody, K., 2012. Species-specific responses ofherbivores to within-plant and environmentally mediated between-plant vari-ability in plant chemistry. Chemoecology 22, 101-111.

34. Has Szymanczuk, E., Lipinska, E. and Stasiuk, M. 2011. The effect of Rosemary preparations on the microbial quality and tbars value of model pork batters. ACTA Scientiarum Polonorum Technol. Aliment, 10(2):165-74. 
35. Hashemi, P., Abolghasemi, M.M., Hassanvand, H., Ahmadi, S., 2010. Headspace solvent microextraction of volatile components of Thymus daenensis. Journal of Essential Oil Research 22 (4), 365-368.

36. Inouye, S., Yamaguchi, H., Takizawa, T. 2001. Screening of the antibacterial effects of a variety of essential oils on respiratory tract pathogens, using a modified dilution assay method. Journal of Infection and Chemotherapy. 7: 251-254.

37. Isman, M. B. and Machial, C. M. 2006. Pesticides based on plant essential oils: From traditional practice to commercialization. pp. 2944. In: Rai, M. and Carpinella, M.C. (eds.), naturally occurring bioactive compounds. Elsevier, Amsterdam, The Netherlands.

38. Jaimand, K. And Rezaei, MB. 2006. Essential Oil, Distillers, Test Methods and Inhibition Index in EOAnalysis, Publication of the Medicinal Plants Association, First Edition.

39. Jamzad,M. A. Rustaiyan, S. Masoudi and Z. Jamzad. 2008. Composition of the essential oils of Nepeta sessilifolia Bunge and Nepeta haussknechtii Bornm. from Iran. J. Essent. Oil Res., 20, 533-535.

40. Kasrati, A., Alaoui, C., Fadli, M., Bekkouche, K., Hassani, L., Wohlmuth, H., Leach, D., Abbad, A., 2014. Antioxidative activity and synergistic effect of Thymus saturejoides Coss. essential oils with cefixime against selected food-borne bacteria. Ind. Crop. Prod. 61, 338-344. https://doi.org/10.1016/j.indcrop.2014.07.024.

41. Khajehie, N., Golmakani, M., Eblaghi, M., Eskandari, M. (2017). Investigating the Effect of Microwaves on Chemical Composition and Antioxidant and Antifungal Activities of Salvia mirzayanii Essential Oil. Research and Innovation in Food Science and Technology, 6(2), 157-170. doi: 10.22101/jrifst.2017.09.02.624.

42. Khanavi, M., Haji mahmoodi, M., Cheraghi- Niroomand, M., Kargar, Z., Ajani, Y., Hadjiakhoondi, A., Ovaisi, R., 2009. Comparison of the antioxidant activity and total phenolic contents in some Stachys species. African Journal of Biotechnology 8: $1143-1147$.

43. Lemos, M.F., Lemos, M.F., Pacheco, H.P., Guimar aes, A.C., Fronza, M., Endringer, D.C., Scherer, R., 2017. Seasonal variation affects the composition and antibacterial and antioxidant activities of Thymus vulgaris. Industrial Crops and Products 95, 543-548.

44. Llorens, L., Llorens-Molina, J. A., Agnello, S., \& Boira, H. 2014. Geographical and environment-related variations of essential oils in isolated populations of Thymus richardii Pers. In the Mediterranean basin. Biochemical Systematics and Ecology, 56, $246-254$.

45. Lopez, P., Sanchez, P., Batlle, C, . 2005. Solid- and vapor-phase antimicrobial activities of six essential oils: susceptibility of selected foodborne bacterial and fungal strains. Journal of Agricultural and Food Chemistry. 53(8):6939-46.

46. Lukas, B., Schmiderer, C., Franz, C., Novak, J., 2009. Composition of essential oil com-pounds from different Syrian populations of Origanum syriacum L. (Lamiaceae).J. Agric. Food Chem. 57, 1362-1365.

47. Mahboubi, M., Heidarytabar, R., Mahdizadeh, E., 2017. Antibacterial activity of Zataria multiflora essential oil and its main components against Pseudomonas aeruginosa. Herba Polonica 63 (3), 18-24.

48. Marzouk, Z., Neffati, A., Marzouk, B. 2006. Chemical composition and antibacterial and antimutagenic activity of Tunisian Rosmarinus officinalis L. oil from Kasrine. Journal of Food, Agriculture \& Environment, 4(3\&4):61-5.

49. Mattanna, P., Da Rosa, P.D., Poli, J., Richards, N.S.P.S., Daboit, T.C., Scroferneker, M.L., Valente, P. 2014. Lipid profile and antimicrobial activity of microbial oils from 16 oleaginous yeasts isolated from artisanal cheese.Rev. Bras. Bioci. 12: $121-126$

50. McGaw, L., Jäger, A., Van Staden, J., 2002. Isolation of antibacterial fatty acids from Schotia brachypetala. Fitoterapia 73, $431-433$.

51. Mehran M, Hoseini H, Hatami A, Taghizade M, Safaie A (M.Sc.). Investigation of Components of Seven Species of Thyme Essential Oils and Comparison of their Antioxidant Properties. J. Med. Plants. 2016; 2 (58):134-140

52. Meshkatalsadat, M.H., Sadeghi Sarabi, R., Moharramipour, S. and Akbari, N. 2007. Chemical constituents of the essential oils of aerial part of the Stachys lavandulifolia Vahl. and Stachys inflata Benth. from Iran. Asian Journal of Chemistry. 19(6):4805-4808

53. Messaoudi Moussi, I., Nayme, K., Timinouni, M. Jamaleddine, J., Filali Hakkou, H. .2019. Synergistic antibacterial effects of Moroccan Artemisia herba alba, Lavandula angustifolia and Rosmarinus officinalis essential oils. Synergy. In Press.

54. Millauskas, G., Venskutonis, P. R. and Van Beek, T. A. (2004) Screening of radical scavenging activity of some medicinal and aromatic plant extracts. Food Chemistry 85: 231-237.

55. Mirza, M., Ahmadi, L. and Tayebi, M. 2001.Volatile constituents of Hymenocrater incanus Bunge, an Iranian endemic species , Flav.\& Fragr. J., 16: 239-240.

56. Mitić, Z.S., Jovanović, B., Jovanović, S., Mihajilov-Krstev, T., Stojanović-Radić, Z.Z., Cvetković, V.J., Mitrović, T.L., Marin, P.D., Zlatković, B.K., Stojanović, G.S., 2018. Comparative study of the essential oils of four Pinusspecies: Chemical composition, antimicrobial and insect larvicidal activity. Ind. Crops Prod. 111, 55-62.

57. Mohsenipour, Z., Hassanshahian, M., 2015. The inhibitory effect of Thymus vulgaris extracts on the planktonic form and biofilm structures of six human pathogenic bacteria. Avicenna Journal of Phytomedicine 5 (4), 309. 
58. Morteza-Semnani K, Saeedi M, Akbarzadeh M. 2010. Chemical composition and antimicrobial activity of the essential oil of Hymenocrater elegans Bunge. J Essent Oil Bear PI. 13:260-266.

59. Morteza-Semnani K, Saeedi M, Akbarzadeh M. 2012. Chemical composition and antimicrobial activity of the essential oil of Hymenocrater calycinus (Boiss.) Benth. J Essent Oil Bear PI. 15:708-714.

60. Morteza-Semnani, K., Akbarzadeh, M. and Changizi, Sh. 2006. Essential oils composition of Stachys byzantina, S. inflata, S. lavandulifolia and S. laxa from Iran. Flavour and fragrance J. 21(2): 300-303.

61. Naeini, A., Khosravi. A., Chitsaz. M., Shokri, H. and Kamlnejad, M. 2009. Anti- Candida albicans activity of some Iranian plants used in traditional medicine. Journal mycologic medicale, 19:168-172.

62. Nejad Ebrahimi, S., Hadian, J., Mirjalili, MH., Sonboli, A., Yousefzadi, M. 2008. Essential oil composition and antibacterial activity of Thymus caramanicus at different phonological stages. Food Chem, 110: 927-31.

63. Nematollahi, H., Emami, Z., Yahyaabadi, S, Shahsar, Sh. 2011. Investigation of antibacterial effect of essential oil of Thymus daenensis. Clinical Biochemistry, 44(13): 5352.

64. Ngahang Kamte SL, Ranjbarian F, Cianfaglione K, . Identification of highly effective antitrypanosomal compounds in essential oils from the Apiaceae family. Ecotoxicol Environ Saf. 2018;156:154-165.

65. Nikavar B And Mojab F. Evaluation of essential oil components of Thyme flowers in the world. Journal of Medicinal Plants. 2004; 13: 50-45

66. Okoh, 00. 2010. Chemical Transformations and Phytochemical Studies of Bioactive Components from Extracts of Rosmarinus Officinalis L . University of Fort Hare.

67. Oluwatuyi, M., Kaatz, G. W., Gibbons, S. 2004. Antibacterial and resistance modifying activity of Rosmarinus officinalis. Phytochemistry, 65:3249-54.

68. Pereiraa,P. S. Maiab, A. J., Tintinob, S. R., Oliveira-Tintinoa, C. D. 2017. Trypanocide, antileishmania and cytotoxic activities of the essential oil from Rosmarinus officinalis $L$ in vitro. Industrial Crops \& Products, 129:724-729.

69. Popović-Djordjević, J., Cengiz, M., Ozer, M.S., Sarikurkcu, C., 2019. Calamintha incana: essential oil composition and biological activity. Ind. Crop. Prod. 128, 162-166.

70. Rajabi, M. Habibipour, R. and Vesaghati Ezatpour, S. 2014. Antibacterial Effects of Extract of Alloe Vera and Stachys Inflata on Gram Positive and Negative Bacteria in In Vitro. Medical Laboratory Journal. 8(3): 15-22.

71. Rašković, A., Milanović, I., Pavlović, N., Ćebović, T., Vukmirović, S., Mikov, M., 2014. Antioxidant activity of rosemary (Rosmarinus officinalis L.) essential oil and its hepatoprotective potential. BMC Complement. Altern. Med. 14, 1-9. https://doi.org/10.1186/14726882-14-225.

72. Risaliti, L., Kehagia, A. Daoultzi, E., Lazari, D. Bergonzi, M.C. Vergkizi- Nikolakaki, S., Hadjipavlou-Litina, D. Bilia, A.R. 2019. Liposomes loaded with Salvia triloba and Rosmarinus officinalis essential oils: In vitro assessment of antioxidant, antiinflammatory and antibacterial activities, Journal of Drug Delivery Science and Technology, doi: https://doi.org/10.1016/j.jddst.2019.03.034.

73. Raut, J.S., Karuppayil, S.M., 2014. A status review on the medicinal properties of essential oils. Ind. Crops Prod. 62, $250-264$.

74. Safaei Ghomi, J., Nahavand, sh., Batooli H. (2011). Studies on the antioxidant activity of the volatile oil and methanol extracts of Nepeta Laxiflora Benth. and Nepeta sessilifolia Bunge, Journal of food Biochemistry, 35, 14086-1492.

75. Safarpoor, M., Ghaedi, M., Asfaram, A., Yousefi-Nejad, M., Javadian, H., Zare Khafri, H., Bagherinasab, M.2018. Ultrasound-assisted extraction of antimicrobial compounds from Thymusdaenensis and Silybum marianum: Antimicrobial activity with and without the presence of natural silver nanoparticles, Ultrason. Sonochem., 42 (2018) 76-83.

76. Sajjadi S E and Khatamsaz M. Composition of the Essential Oil of Thymus daenensis Celak. ssp. lancifolius (Celak.) Jalas. J. Essent. Oil Res. 2003; 15: 34 - 5.

77. Sajjadi, S. E., Somae, M. 2004. Chemical Composition of the Essential Oil of Stachys inflata Benth. from Iran. Chemistry of Natural Compounds. 40(4): 378-380.

78. Sales-Campos, H., de Souza, P.R., Peghini, B.C., da Silva, J.S., and Cardoso, C.R. 2013. An overview of the modulatory effects of oleic acid in health and disease. Mini Rev Med Chem. 13:201-210.

79. Sampaio, B. L. and Batista D. C. F. 2017. Articlelnfluence of abiotic environmental factors on the main constituentsof the volatile oils of Tithonia diversifolia. Revista Brasileira de Farmacognosia. 28(2): 1-10.

80. Silva, V.P., Alves, C.C., Miranda, M.L., Bretanha, L.C., Balleste, M.P., Micke, G.A., Silveira, E.V., Martins, C.H., Ambrosio, M.A., Silva, T.D., Tavares, D.C., Magalhães, L.G., Silva, F.G., \& Egea, M.B. (2018). Chemical composition and in vitro leishmanicidal, antibacterial and 
cytotoxic activities of essential oils of the Myrtaceae family occurring in the Cerrado biome. Industrial Crops and Products, 123, 638645.

81. Sokmen M, Serkedjieva J, Daferera D, Gulluce M, Polissiou M, Tepe B, . In Vitro Antioxidant, Antimicrobial, and Antiviral Activities of the Essential oil and Various Extracts from Herbal Parts and Cullus Cultures of Origanum acutidens. J Agric food Chem. 2004; 52(11):3309-3312.

82. Stojanović-Radić, Z., Pejčić, M., Joković, N., Jokanović, M., Ivić, M., Šojić, B., Škaljac, S., Stojanovic, P., Mihajilov-Krstev, T., 2018. Inhibition of Salmonella enteritidis growth and storage stability in chicken meat treated with basil and rosemary essential oils alone or in combination. Food Control 90, 332-343.

83. Taft, S., Najar, A., Godbout, J., Bousquet, J., Erbilgin, N., 2015. Variations in foliar monoterpenes across the range of jack pine reveal threewidespread chemotypes: implications to host expansion of invasivemountain pine beetle. Frontiers in Plant Science 6, 342.

84. Takayama, C., de-Faria, F.M., de Almeida, A.C.A., Dunder, R.J., Manzo, L.P., Socca, E.A.R., Batista, L.M., Salvador, M.J., Souza-Brito, A.R.M., Luiz-Ferreira, A., 2016. Chemical composition of Rosmarinus officinalis essential oil and antioxidant action against gastric damage induced by absolute ethanol in the rat. Asian Pac. J. Trop. Biomed. 6, 677-681. https://doi.org/10.1016/j.apjtb.2015.09.027

85. Talebi, S. M., Ghorbani Nohooji, M., Yarmohammadi, M., Khani, M. and Matsyura, A. 3. Effect of altitude on essential oil composition and on glandular trichome density in three Nepeta species (N. sessilifolia, N. heliotropifolia and N. fissa). Mediterranean Botany, 40(1) 2019: 81-93.

86. Tavassoli, S., Mousavi, S. M., Emam-Djomeh, Z 2011. Comparative Study of the Antimicrobial Activity of Rosmarinus officinalis L. Essential Oil and Methanolic Extract. Middle-East Journal of Scientific Research, 9(4):467-71.

87. Tawfeeq, A., Culham, A., Davis, F., Reeves, M., 2016. Does fertilizer type and method of application cause significant differences in essential oil yield and composition in rosemary (Rosmarinus officinalis L.). Ind. Crops Prod. 88, 17-22. https://doi.org/10.1016/j.indcrop.2016.03.026

88. Teimouri, M. 2012. Antimicrobial activity and essential oil composition of Thymus daenensis Celak. from Iran. J Med Plants Res. 6, $631-635$.

89. Telascrea, M., de Araújo, C.C., Marques, M.O.M., Facanali, R. and de Moraes, P.L.R. 2007. Cavalheiro, A.J. Essential oil leaves of Cryptocarya mandioccana Meisner (Lauraceae): Composition and intraspecific chemical variability. Biochem. Syst. Ecol. 35 : $22-232$.

90. Tohidi, B., Mehdi Rahimmalek, Ahmad Arzani. 2017. Essential oil composition, total phenolic, flavonoid contents, and antioxidant activity of Thymus species collected from different regions of Iran. Food Chemistry, 220:153-161.

91. Toyoshi, U., Kimiyo, N., Hiroyasu, I., Kiyomi, K., Misao, S., Masatoshi, M.2006. Anticonflict effects of lavender oil and identification of its active constituents. Pharmacology Biochemistry and Behavior, 85:713-721.

92. Ultee, A., Kets, T. P. W. and Smid, E. J. 1999. Mechanisms of action of carvacrol on the food-borne pathogen Bacillus cereus. Appl. and Environ. Microbiol. 65: 4606-4610.

93. Villanueva-Bermejo, D., Angelov, I., Vicente, G., Stateva, R. P., Rodriguez García-Risco, M., Reglero, G., Ibañez, E. and Fornari, T. 2015. Extraction of thymol from different varieties of thyme plants using green solvents. Journal of Science of Food and Agriculture. 95(14): 2901-290.

94. Weisany,W., Jahanshir Aminib, Saadi Samadic, Somaieh Hossainib, Shima Yousefia,Paul C. Struikd. 2019. Nano silver-encapsulation of Thymus daenensis and Anethum graveolens essential oils enhances antifungal potential against strawberry anthracnose. Industrial Crops and Products, 141, 111808.

95. Wetwitayaklung, P., Thavanapong, N., Charoenteeraboon, J., 2009. Chemical constituents and antimicrobial activity of essential oil and extracts of heartwood of Aquilaria crassna obtained from water distillation and supercritical fluid carbon dioxide extraction. Silpakorn U. Sci. Technol. J. 3, 25-33.

96. Yavari, A.R., Nazeri, V., Sefidkon, F. and Hassani, M.E. 2010. Evaluation of some ecological factors, morphological traits and EOproductivity of Thymus migricus Klokov \& Desj.-Shost. Iranian Journal of Medicinal and Aromatic Plants. 26(2): $227-238$.

97. Zaidi MA, Crow SA Jr. 2005. Biologically active traditional medicinal herbs from Balochistan, Pakistan. J Ethnopharmacol. 96:331334.

98. Zarshenas, M.M., Krenn, L., 2015. A critical overview on Thymus daenensis celak.: phytochemical and pharmacological investigations. European Journal of Integrative Medicine 13 (2), 91-98.

99. Zargari A. Medicinal Plants. 7th Edition. Tehran: Tehran University publication; 2012; p121.

100. Zuzarte, M., Salgueiro, L., 2015. Essential oils chemistry. In: de Sousa, D. (Ed.), Bioactive Essential Oils and Cancer. Springer, pp. $19-61$.

\section{Tables}

Page 14/21 
Table 1. Analysis of variance of species effects on yield and some predominant compounds of essential oils of five Lamiaceae species

\begin{tabular}{|c|c|c|c|c|c|c|c|}
\hline \multirow{3}{*}{$\begin{array}{l}\text { Source of } \\
\text { variation }\end{array}$} & \multirow{3}{*}{$\mathrm{df}$} & \multicolumn{5}{|c|}{ MS } & \multirow[b]{3}{*}{ Linalool } \\
\hline & & Yield of essential oil & & & & & \\
\hline & & & 1,8-Cineole & Oleic acid & (-)-Caryophyllene oxide & trans-Caryophyllene & \\
\hline species & 4 & $1.790 \star \star$ & $191.383^{\star *}$ & $1887.685^{\star \star}$ & $348.869 * \star$ & $7.305^{\star \star}$ & $3.691 \star \star *$ \\
\hline Error & 10 & 0.000015 & 0.000021 & 0.000033 & 0.000003 & 0.000027 & 0.000060 \\
\hline
\end{tabular}

ns: Not significant, **: $1 \%$ level of probability is significant

Table 2. Comparison of the mean of species on the yield of essential oil of five Lamiaceae species

\begin{tabular}{ll} 
species & Mean $(\%) \pm \mathrm{SD}$ \\
\hline T. daenensis & $1.88 \pm 0.01^{\mathrm{a}}$ \\
\hline N. sessilifolia & $0.20 \pm 0.01^{\mathrm{c}}$ \\
\hline H. incanus & $0.02 \pm 0.00^{\mathrm{e}}$ \\
\hline S. inflate & $0.14 \pm 0.00^{\mathrm{d}}$ \\
\hline R. officinalis & $0.83 \pm 0.00^{\mathrm{b}}$
\end{tabular}

The different letters indicate a significant difference based on Duncan's multiple range test at the $1 \%$ level.

Table 3.The chemical composition of EOs from five Lamiaceae species. 


\begin{tabular}{|c|c|c|c|c|c|c|c|c|}
\hline No. & Compound (\%) & $\mathrm{RI}$ & TDEO & NSEO & HIEO & SIEO & ROEO & $\begin{array}{l}\text { Molecular } \\
\text { formula }\end{array}$ \\
\hline 1 & Tricyclene & 860.095 & - & - & - & - & $\begin{array}{l}0.63 \pm \\
0.00^{\mathrm{a}}\end{array}$ & $\mathrm{C}_{10} \mathrm{H}_{16}$ \\
\hline 1 & a-Thujene & 863.546 & $\begin{array}{l}0.85 \pm \\
0.01^{a}\end{array}$ & $\begin{array}{l}0.39 \pm \\
0.01^{b}\end{array}$ & - & - & - & $\mathrm{C}_{10} \mathrm{H}_{16}$ \\
\hline 2 & a-pinene & 871.428 & $\begin{array}{l}1.09 \pm \\
0.02^{c}\end{array}$ & - & - & $\begin{array}{l}1.52 \pm \\
0.01^{b}\end{array}$ & $\begin{array}{l}19.41 \pm \\
0.01^{a}\end{array}$ & $\mathrm{C}_{10} \mathrm{H}_{16}$ \\
\hline 3 & Camphene & 888.177 & $\begin{array}{l}0.82 \pm \\
0.01^{b}\end{array}$ & - & - & $\begin{array}{l}0.55 \pm \\
0.00^{c}\end{array}$ & $\begin{array}{l}7.83 \pm \\
0.01^{a}\end{array}$ & $\mathrm{C}_{10} \mathrm{H}_{16}$ \\
\hline 4 & Sabinene & 908.276 & - & $\begin{array}{l}0.33 \pm \\
0.01^{a}\end{array}$ & - & - & - & $\mathrm{C}_{10} \mathrm{H}_{16}$ \\
\hline 5 & $\beta$-pinene & 912.251 & $\begin{array}{l}0.43 \pm \\
0.01^{b}\end{array}$ & - & - & - & $\begin{array}{l}2.56 \pm \\
0.00^{a}\end{array}$ & $\mathrm{C}_{10} \mathrm{H}_{16}$ \\
\hline 6 & $\beta$-Myrcene & 920.529 & $\begin{array}{l}1.50 \pm \\
0.01^{\mathrm{b}}\end{array}$ & - & - & - & $\begin{array}{l}5.38 \pm \\
0.01^{a}\end{array}$ & $\mathrm{C}_{10} \mathrm{H}_{16}$ \\
\hline 7 & a-Phellandrene & 932.781 & $\begin{array}{l}0.28 \pm \\
0.00^{\mathrm{b}}\end{array}$ & - & - & - & $\begin{array}{l}0.64 \pm \\
0.00^{a}\end{array}$ & $\mathrm{C}_{10} \mathrm{H}_{16}$ \\
\hline 8 & a-Terpinene & 942.715 & $\begin{array}{l}1.71 \pm \\
0.00^{\mathrm{a}}\end{array}$ & - & - & - & $\begin{array}{l}0.38 \pm \\
0.01^{b}\end{array}$ & $\mathrm{C}_{10} \mathrm{H}_{16}$ \\
\hline 9 & p-Cymene & 952.649 & $\begin{array}{l}5.16 \pm \\
0.00^{a}\end{array}$ & - & - & - & - & $\mathrm{C}_{10} \mathrm{H}_{14}$ \\
\hline 10 & 1,8-Cineole & 957.284 & $\begin{array}{l}3.52 \pm \\
0.00^{\mathrm{b}}\end{array}$ & $\begin{array}{l}0.91 \pm \\
0.00^{d}\end{array}$ & $\begin{array}{l}0.22 \pm \\
0.00^{\mathrm{e}}\end{array}$ & $\begin{array}{l}1.65 \pm \\
0.00^{c}\end{array}$ & $\begin{array}{l}15.40 \pm \\
0.01^{a}\end{array}$ & $\mathrm{C}_{10} \mathrm{H}_{18} \mathrm{O}$ \\
\hline 11 & ү-Terpinene & 979.801 & $\begin{array}{l}6.20 \pm \\
0.01^{a}\end{array}$ & - & - & - & $\begin{array}{l}0.42 \pm \\
0.01^{b}\end{array}$ & $\mathrm{C}_{10} \mathrm{H}_{16}$ \\
\hline 12 & a-Terpinolene & 1002.375 & $\begin{array}{l}0.26 \pm \\
0.01^{b}\end{array}$ & - & - & - & $\begin{array}{l}0.87 \pm \\
0.00^{a}\end{array}$ & $\mathrm{C}_{10} \mathrm{H}_{16}$ \\
\hline 13 & Linalool & 1012.962 & $\begin{array}{l}0.67 \pm \\
0.01^{d}\end{array}$ & $\begin{array}{l}1.45 \pm \\
0.01^{\mathrm{b}}\end{array}$ & - & $\begin{array}{l}1.20 \pm \\
0.01^{c}\end{array}$ & $\begin{array}{l}2.97 \pm \\
0.01^{a}\end{array}$ & $\mathrm{C}_{10} \mathrm{H}_{18} \mathrm{O}$ \\
\hline 14 & Chrysanthenone & 1029.894 & & - & - & - & $\begin{array}{l}1.27 \pm \\
0.01^{\mathrm{a}}\end{array}$ & $\mathrm{C}_{10} \mathrm{H}_{14} \mathrm{O}$ \\
\hline 15 & Camphor & 1043.915 & & - & - & $\begin{array}{l}1.67 \pm \\
0.00^{b}\end{array}$ & $\begin{array}{l}8.87 \pm \\
0.00^{a}\end{array}$ & $\mathrm{C}_{10} \mathrm{H}_{16} \mathrm{O}$ \\
\hline 16 & trans-Pinocamphone & 1050.118 & & - & - & - & $\begin{array}{l}0.87 \pm \\
0.01^{a}\end{array}$ & $\mathrm{C}_{10} \mathrm{H}_{16} \mathrm{O}$ \\
\hline 17 & Silane, tetraethenyl- & 1060.846 & & - & - & - & $\begin{array}{l}0.31 \pm \\
0.01^{a}\end{array}$ & $\mathrm{C}_{8} \mathrm{H}_{12} \mathrm{Si}$ \\
\hline 18 & Borneol & 1064.021 & $\begin{array}{l}3.67 \pm \\
0.01^{b}\end{array}$ & - & & $\begin{array}{l}1.17 \pm \\
0.01^{c}\end{array}$ & $\begin{array}{l}8.48 \pm \\
0.00^{a}\end{array}$ & $\mathrm{C}_{10} \mathrm{H}_{18} \mathrm{O}$ \\
\hline 19 & Terpinen-4-ol & 1070.105 & & - & & - & $\begin{array}{l}1.62 \pm \\
0.01^{a}\end{array}$ & $\mathrm{C}_{10} \mathrm{H}_{18} \mathrm{O}$ \\
\hline 20 & a-Terpineol & 1080.158 & - & $\begin{array}{l}0.50 \pm \\
0.01^{c}\end{array}$ & - & $\begin{array}{l}0.91 \pm \\
0.00^{\mathrm{b}}\end{array}$ & $\begin{array}{l}1.95 \pm \\
0.01^{a}\end{array}$ & $\mathrm{C}_{10} \mathrm{H}_{18} \mathrm{O}$ \\
\hline 21 & 1,2-Cyclononadiene & 1087.830 & $\begin{array}{l}1.19 \pm \\
0.02^{a}\end{array}$ & - & - & - & - & $\mathrm{C}_{9} \mathrm{H}_{14}$ \\
\hline 22 & Myrtenol & 1088.095 & - & - & - & - & $\begin{array}{l}0.33 \pm \\
0.01^{a}\end{array}$ & $\mathrm{C}_{10} \mathrm{H}_{16} \mathrm{O}$ \\
\hline
\end{tabular}




\begin{tabular}{|c|c|c|c|c|c|c|c|c|}
\hline 23 & Verbenone & 1092.592 & - & - & - & $\begin{array}{l}2.20 \pm \\
0.01^{b}\end{array}$ & $\begin{array}{l}8.28 \pm \\
0.00^{a}\end{array}$ & $\mathrm{C}_{10} \mathrm{H}_{14} \mathrm{O}$ \\
\hline 24 & Thymol & 1169.951 & $\begin{array}{l}67.71 \pm \\
0.00^{a}\end{array}$ & - & - & - & - & $\mathrm{C}_{10} \mathrm{H}_{14} \mathrm{O}$ \\
\hline 25 & Urea, phenyl- & 1113.942 & - & - & - & - & $\begin{array}{l}1.02 \pm \\
0.01^{a}\end{array}$ & $\mathrm{C}_{7} \mathrm{H}_{8} \mathrm{~N}_{2} \mathrm{O}$ \\
\hline 26 & Tricyclo[4.2.1.1(2,5)]decane & 1117.788 & - & - & - & - & $\begin{array}{l}1.43 \pm \\
0.01^{a}\end{array}$ & $\mathrm{C}_{10} \mathrm{H}_{16}$ \\
\hline 27 & Acetic acid, bornyl ester & 1128.846 & - & - & - & $\begin{array}{l}1.29 \pm \\
0.010^{a}\end{array}$ & - & $\mathrm{C}_{12} \mathrm{H}_{20} \mathrm{O}_{2}$ \\
\hline 28 & trans-Bornyl acetate & 1137.019 & - & - & - & - & $\begin{array}{l}4.77 \pm \\
0.01^{a}\end{array}$ & $\mathrm{C}_{12} \mathrm{H}_{20} \mathrm{O}_{2}$ \\
\hline 29 & $\begin{array}{l}\text { 1,5,5-Trimethyl-6-methylene- } \\
\text { cyclohexene }\end{array}$ & 1166.105 & - & - & - & $\begin{array}{l}0.83 \pm \\
0.01^{a}\end{array}$ & - & $\mathrm{C}_{10} \mathrm{H}_{16}$ \\
\hline 30 & a-Copaene & 1190.865 & - & - & - & $\begin{array}{l}0.69 \pm \\
0.01^{a}\end{array}$ & - & $\mathrm{C}_{15} \mathrm{H}_{24}$ \\
\hline 31 & $\beta$-Bourbonene & 1197.115 & - & $\begin{array}{l}1.03 \pm \\
0.02^{a}\end{array}$ & - & - & - & $\mathrm{C}_{15} \mathrm{H}_{24}$ \\
\hline 32 & $\beta$-Elemene & 1200.947 & & - & - & $\begin{array}{l}1.12 \pm \\
0.01^{a}\end{array}$ & - & $\mathrm{C}_{15} \mathrm{H}_{24}$ \\
\hline 33 & trans-Caryophyllene & 1224.489 & $\begin{array}{l}2.99 \pm \\
0.01^{b}\end{array}$ & $\begin{array}{l}0.67 \pm \\
0.01^{d}\end{array}$ & $\begin{array}{l}3.68 \pm \\
0.01^{a}\end{array}$ & - & $\begin{array}{l}1.24 \pm \\
0.01^{c}\end{array}$ & $\mathrm{C}_{15} \mathrm{H}_{24}$ \\
\hline 34 & (+)-Aromadendrene & 1232.464 & $\begin{array}{l}0.15 \pm \\
0.00^{\mathrm{a}}\end{array}$ & - & - & - & $\begin{array}{l}0.24 \pm \\
0.01^{a}\end{array}$ & $\mathrm{C}_{15} \mathrm{H}_{24}$ \\
\hline 35 & a-Humulene & 1238.862 & - & - & $\begin{array}{l}1.50 \pm \\
0.01^{a}\end{array}$ & - & - & $\mathrm{C}_{15} \mathrm{H}_{24}$ \\
\hline 36 & Alloaromadendrene & 1242.417 & - & - & $\begin{array}{l}0.29 \pm \\
0.01^{a}\end{array}$ & - & - & $\mathrm{C}_{15} \mathrm{H}_{24}$ \\
\hline 37 & a-Amorphene & 1250.947 & - & - & - & $\begin{array}{l}0.92 \pm \\
0.00^{\mathrm{a}}\end{array}$ & - & $\mathrm{C}_{15} \mathrm{H}_{24}$ \\
\hline 38 & $\beta$-Cubebene & 1254.028 & - & $\begin{array}{l}0.26 \pm \\
0.01^{a}\end{array}$ & - & - & - & $\mathrm{C}_{15} \mathrm{H}_{24}$ \\
\hline 39 & Germacrene D & 1254.502 & - & - & $\begin{array}{l}0.30 \pm \\
0.01^{b}\end{array}$ & $\begin{array}{l}10.26 \pm \\
0.01^{a}\end{array}$ & - & $\mathrm{C}_{15} \mathrm{H}_{24}$ \\
\hline 40 & Bicyclogermacrene & 1263.033 & - & - & $\begin{array}{l}0.57 \pm \\
0.00^{b}\end{array}$ & $\begin{array}{l}9.19 \pm \\
0.01^{a}\end{array}$ & - & $\mathrm{C}_{15} \mathrm{H}_{24}$ \\
\hline 41 & $\beta$-Bisabolene & 1268.009 & $\begin{array}{l}0.50 \pm \\
0.01^{\mathrm{a}}\end{array}$ & - & - & - & - & $\mathrm{C}_{15} \mathrm{H}_{24}$ \\
\hline 42 & $\delta$-cadinene & 1276.540 & - & $\begin{array}{l}0.34 \pm \\
0.00^{b}\end{array}$ & - & $4.7 \pm 0.01^{a}$ & - & $\mathrm{C}_{15} \mathrm{H}_{24}$ \\
\hline 43 & cis-a-Bisabolene & 1286.255 & $\begin{array}{l}0.40 \pm \\
0.00^{\mathrm{a}}\end{array}$ & - & - & - & - & $\mathrm{C}_{15} \mathrm{H}_{24}$ \\
\hline 44 & $\begin{array}{l}\text { Phenol, 2,4-bis(1,1- } \\
\text { dimethylethyl)- }\end{array}$ & 1294.163 & - & - & $\begin{array}{l}0.95 \pm \\
0.01^{a}\end{array}$ & - & - & $\mathrm{C}_{14} \mathrm{H}_{22} \mathrm{O}$ \\
\hline 45 & Elemol & 1296.208 & - & $\begin{array}{l}0.24 \pm \\
0.00^{a}\end{array}$ & - & - & - & $\mathrm{C}_{15} \mathrm{H}_{26} \mathrm{O}$ \\
\hline 46 & 4,7-Methano-5H-inden-5-one, & 1296.445 & - & - & $0.41 \pm$ & - & - & $\mathrm{C}_{10} \mathrm{H}_{14} \mathrm{O}$ \\
\hline
\end{tabular}


octahydro-

Furan, 2-(2-furanylmethyl)-5-
methyl-

48

49 (-)-Caryophyllene oxide

$50 \quad$ Viridiflorol

51 (-)-Humulene epoxide II

52 a-Chamigrene

53 a-Cadinol

54 Caryophylla-3,8(13)-dien-5ß-ol

55 Caryophyllenol-II

56 (3S,4R,5S,6R,7S)-aristol-9-en-3-ol

$57 \quad$ Myristic acid

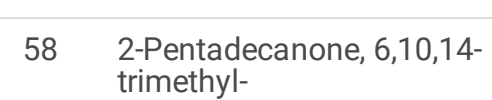

59 Phthalic acid

60 Tridecane

61 Hexadecanoic acid= Palmitic acid

62 Phytol

63 Oleic acid

64 Stearic acid

$65 \quad$ Linoleic acid

66 Lauric acid

Total

Monoterpenes hydrocarbons

Oxygenated monoterpenes

Sesquiterpenes hydrocarbons

Oxygenated sesquiterpenes

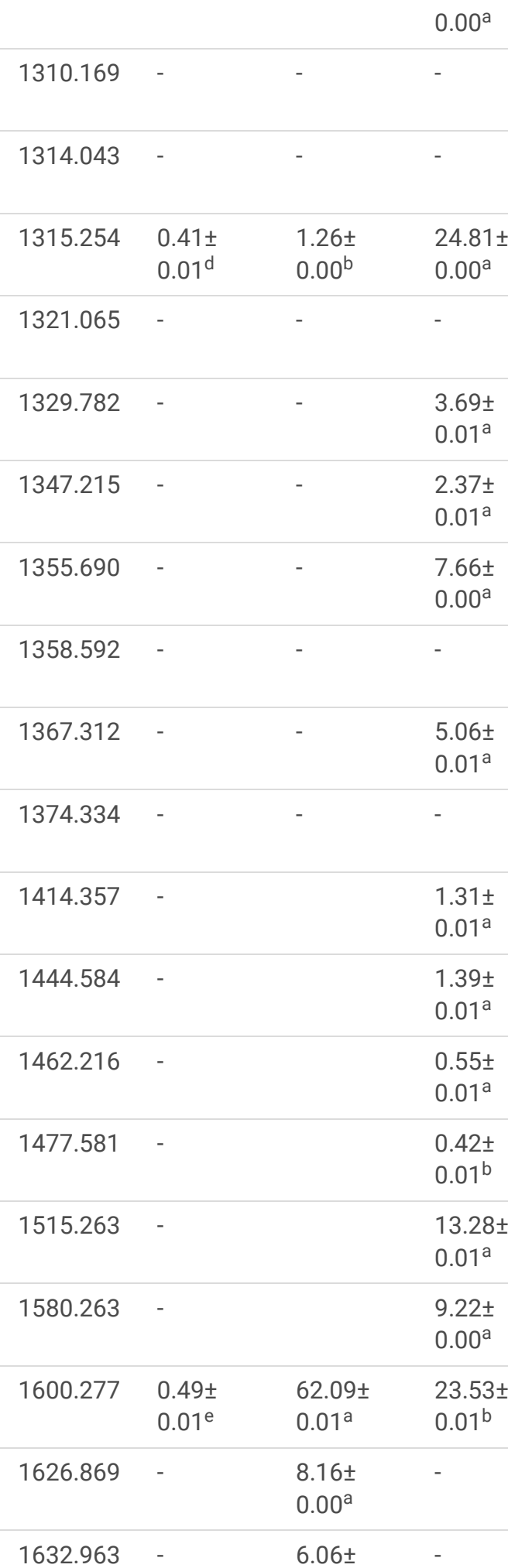

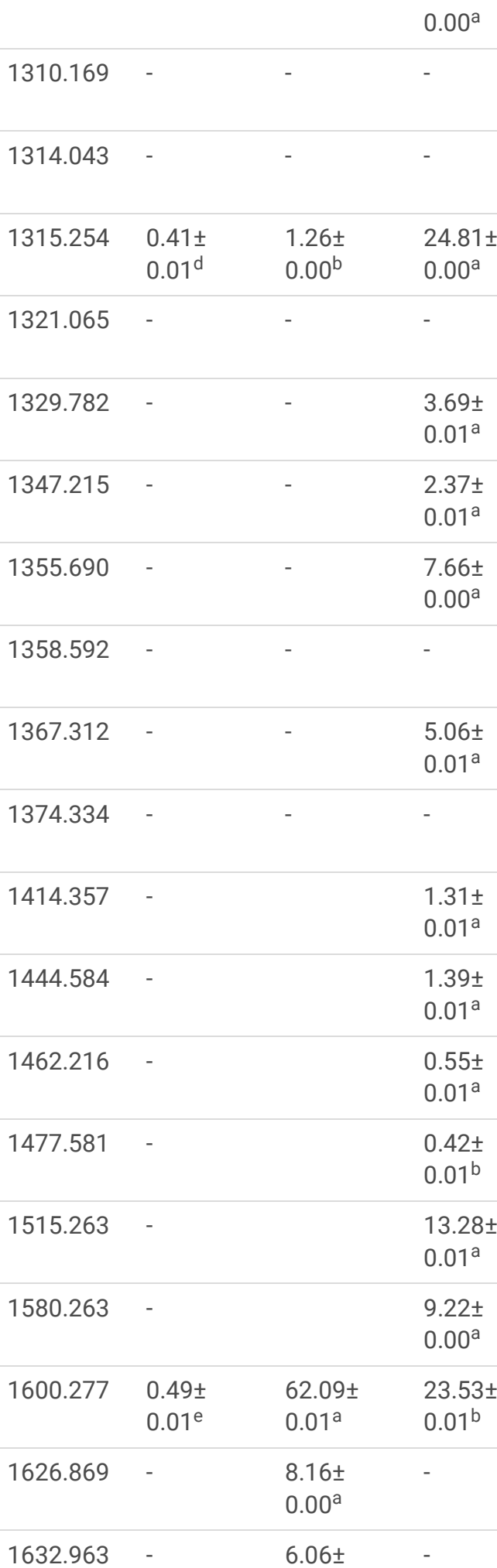

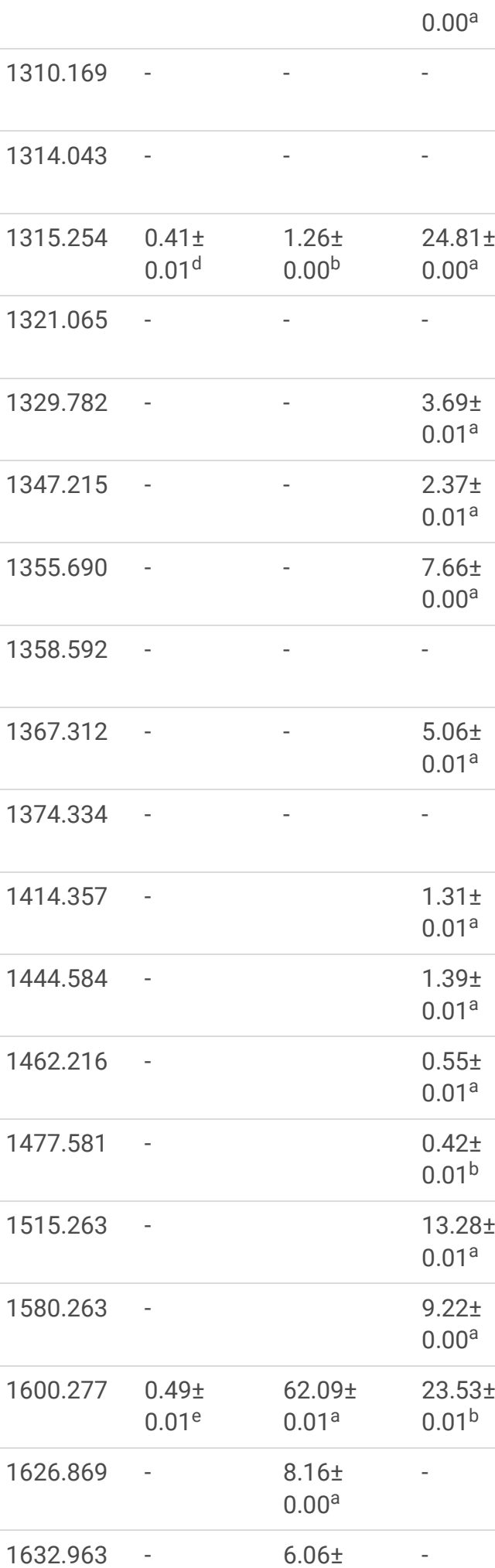

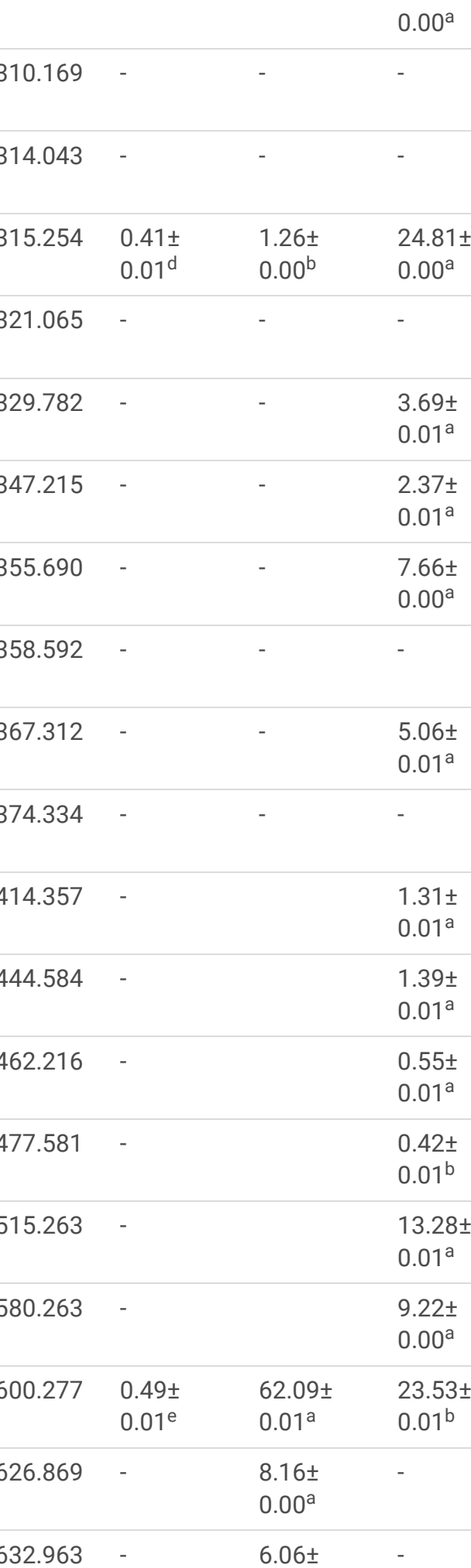

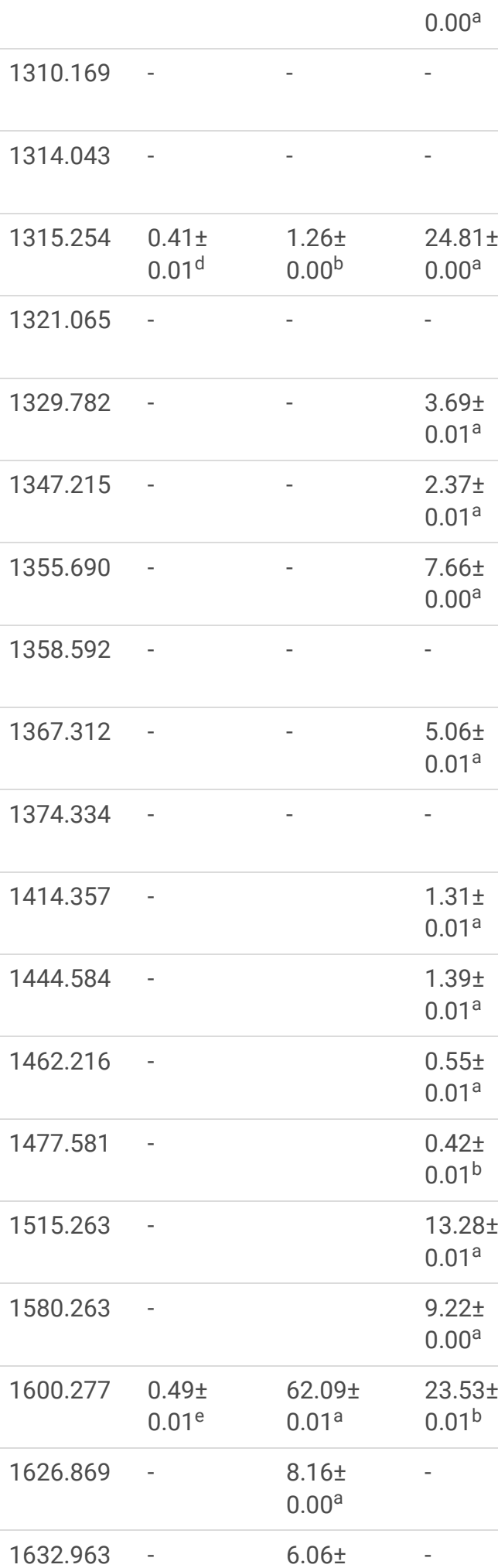

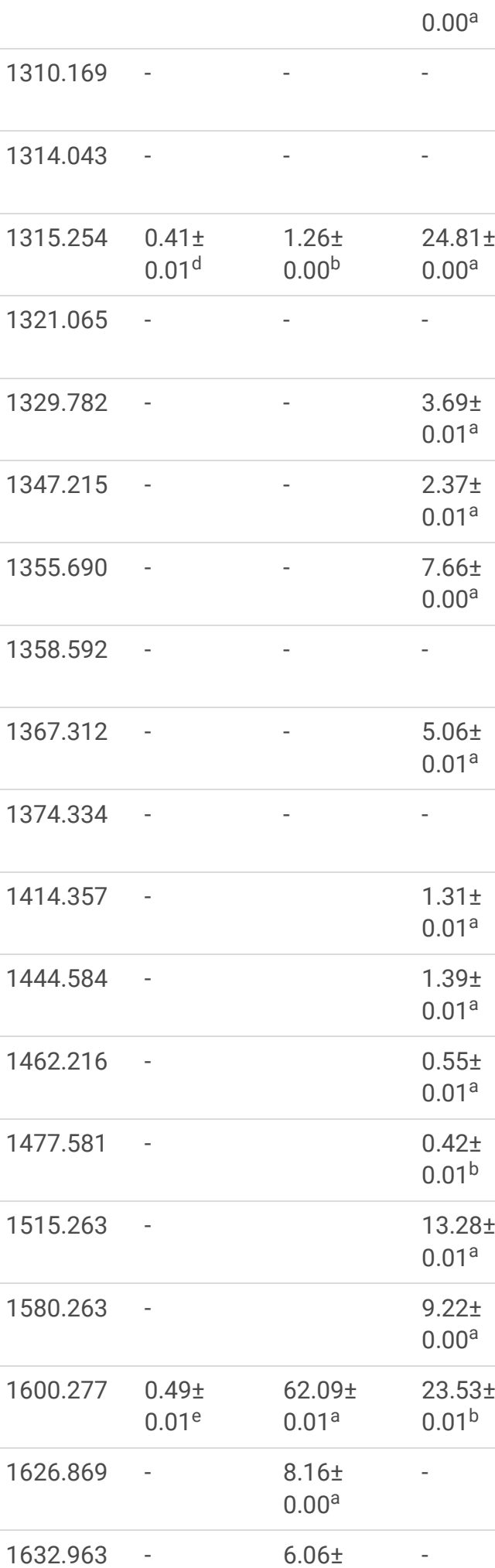

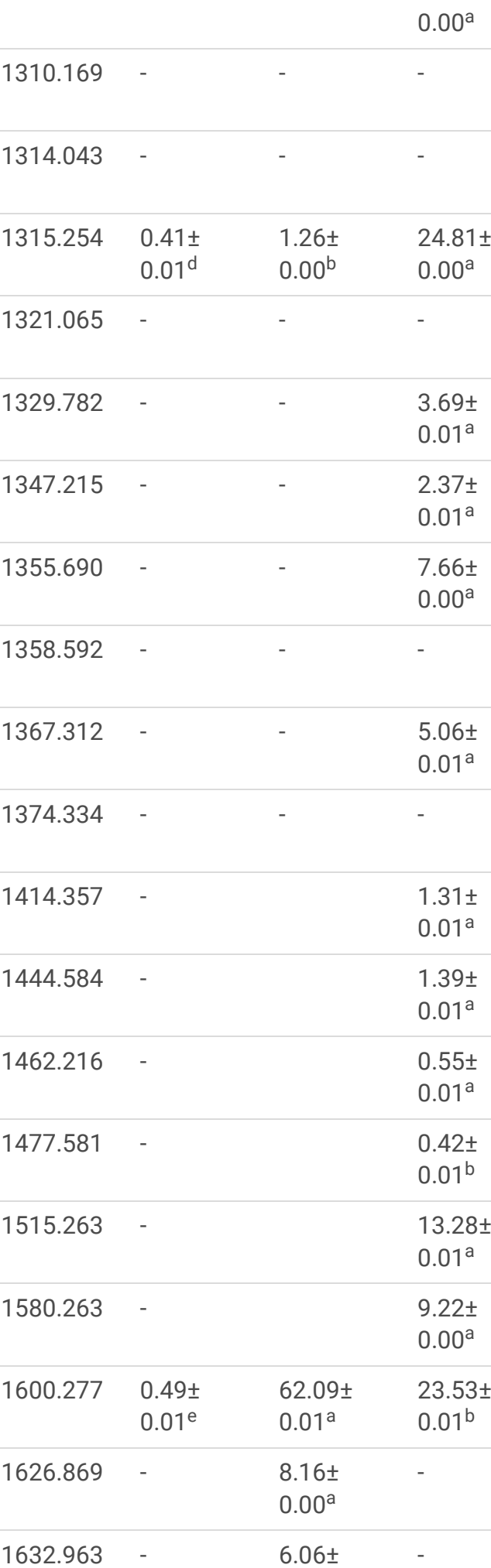

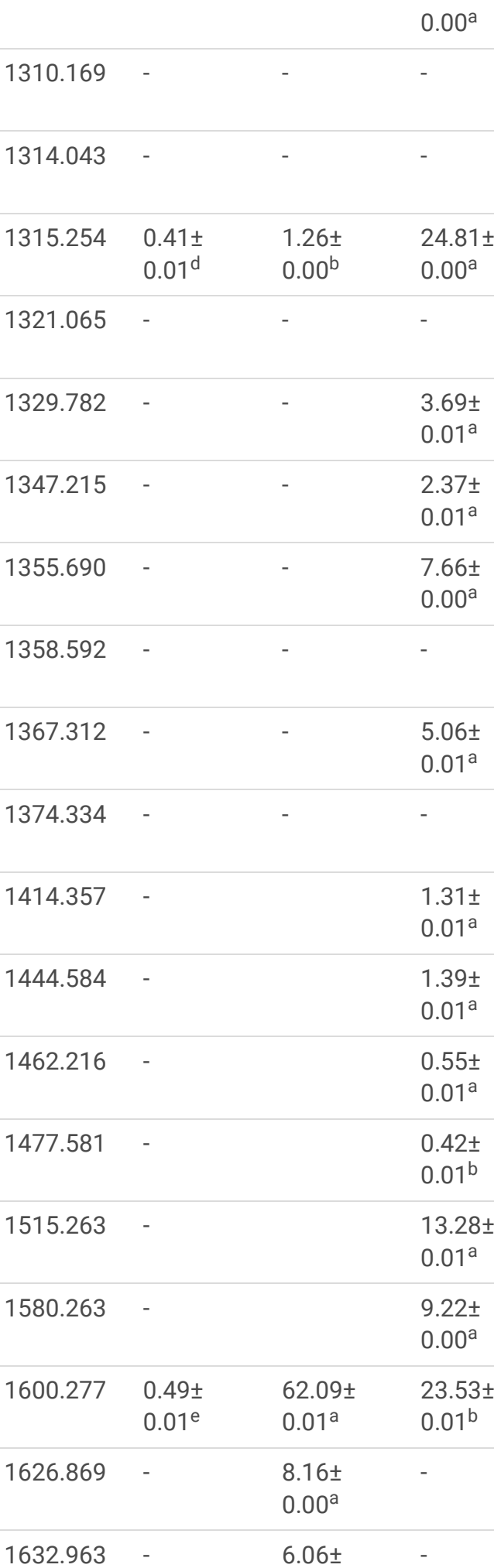

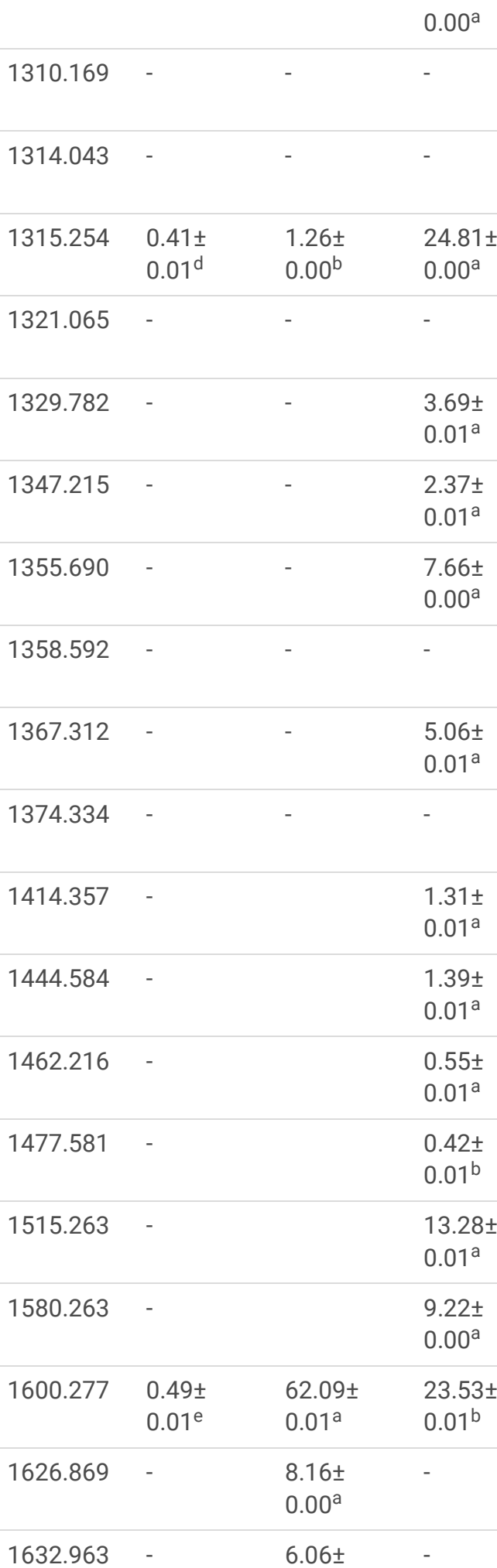

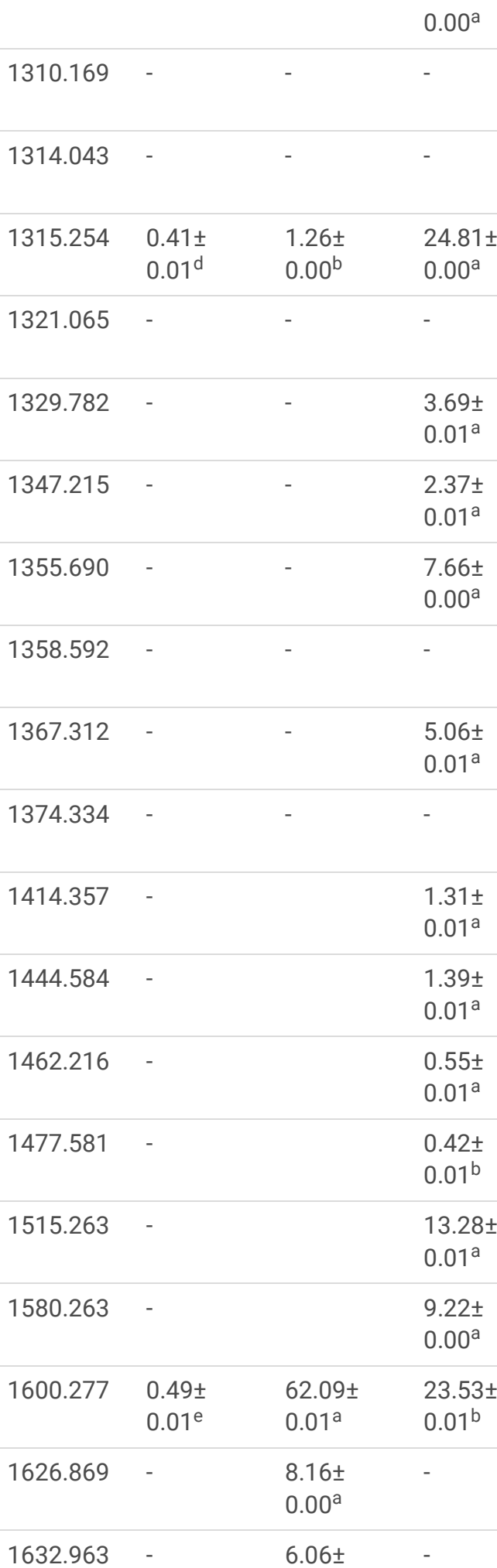

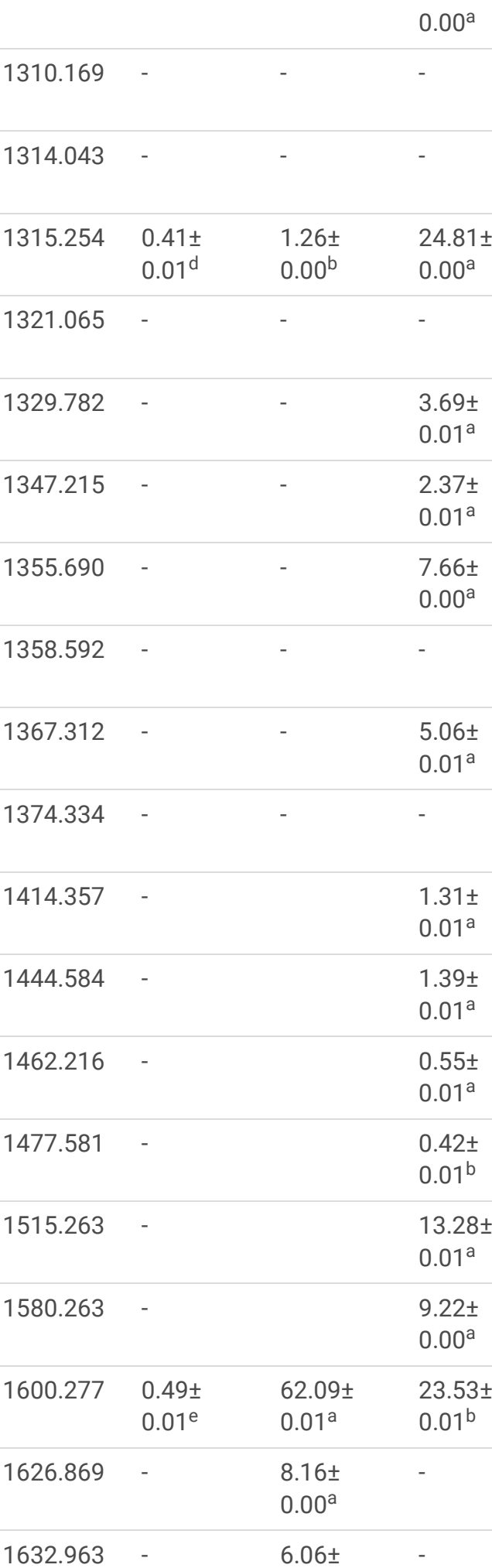

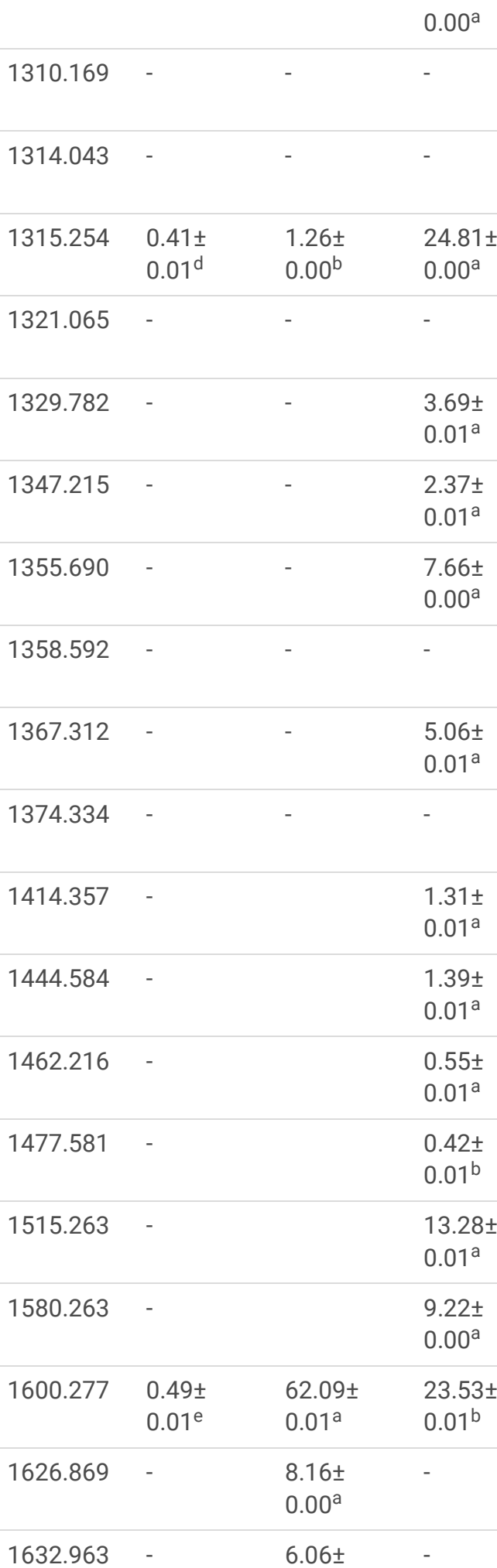

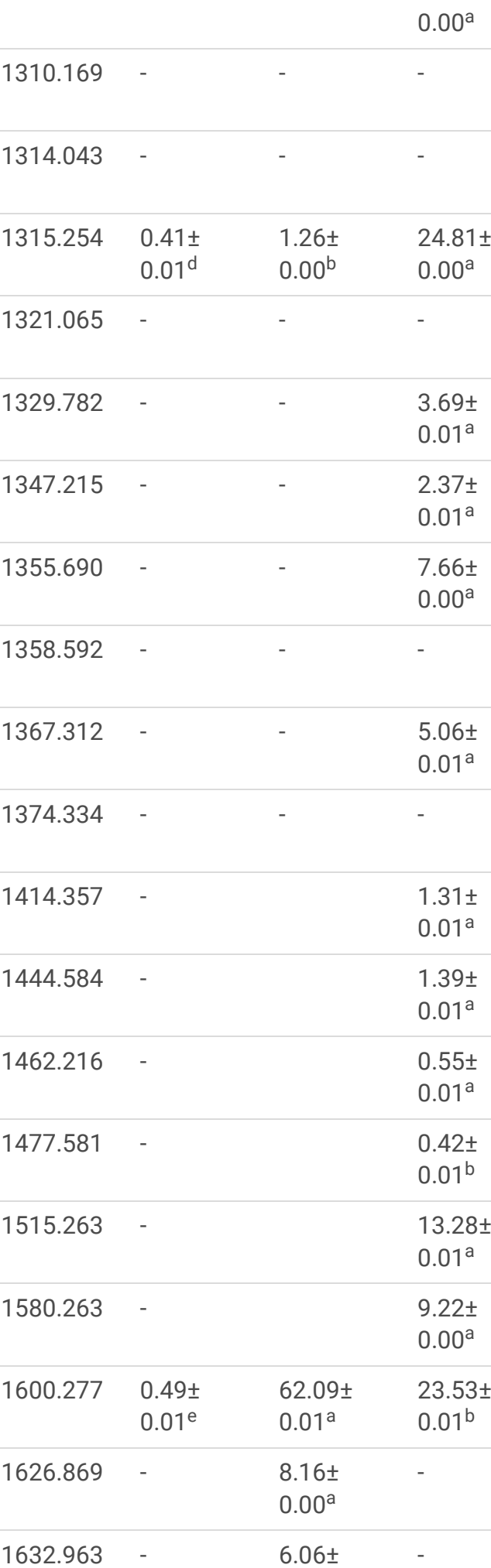

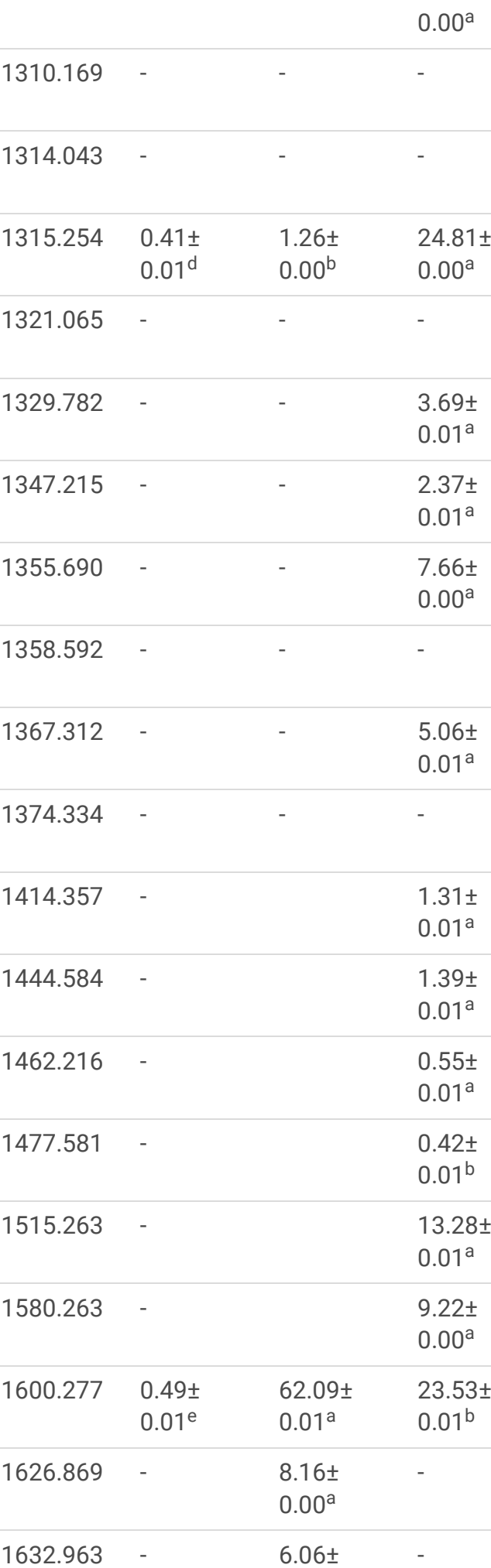

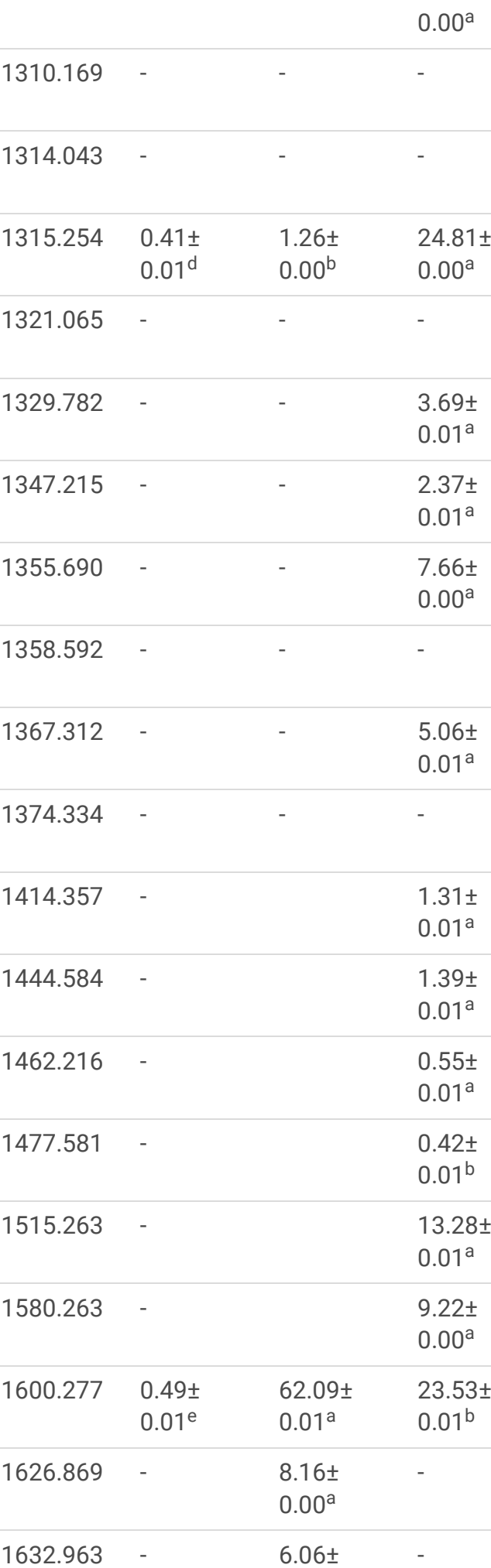

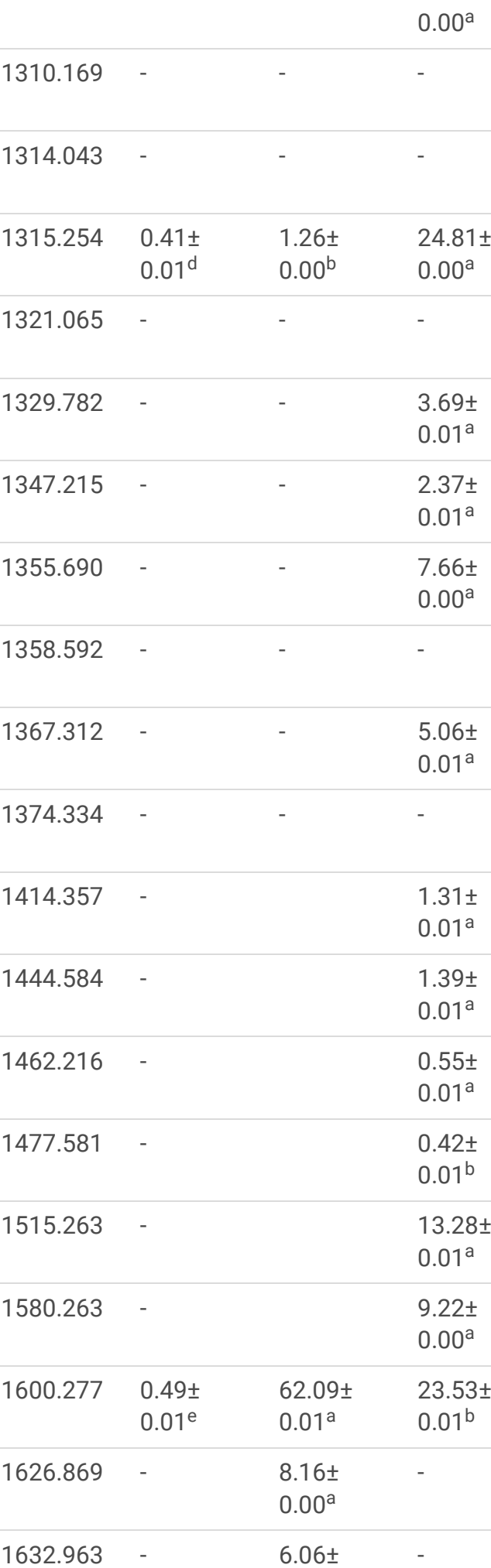

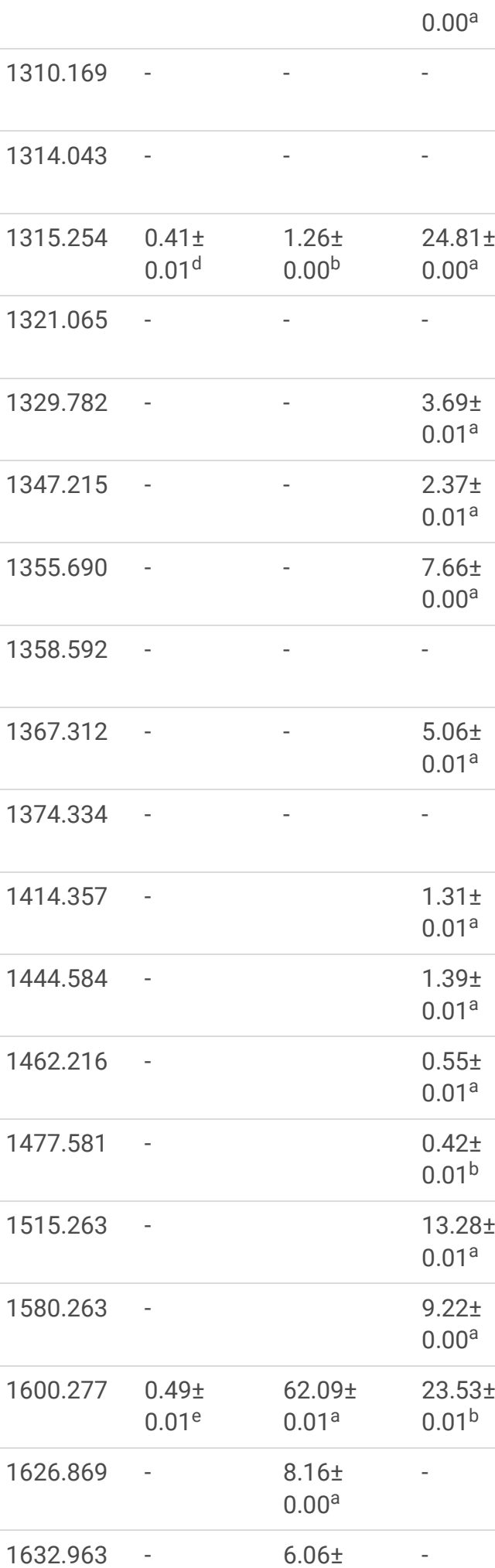

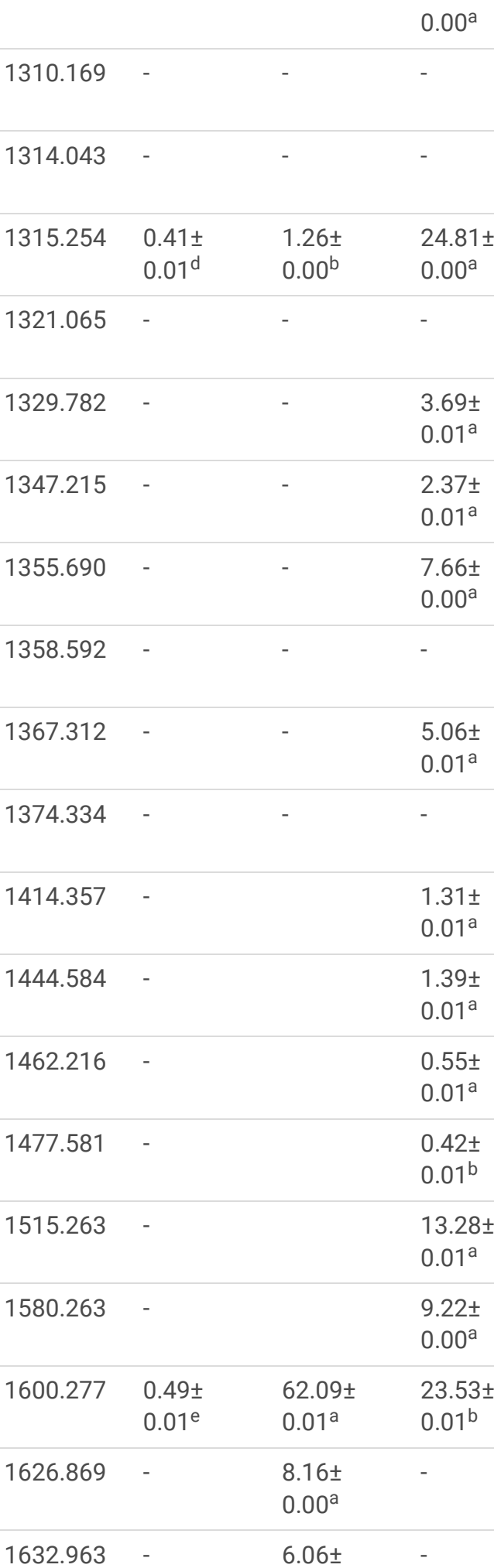

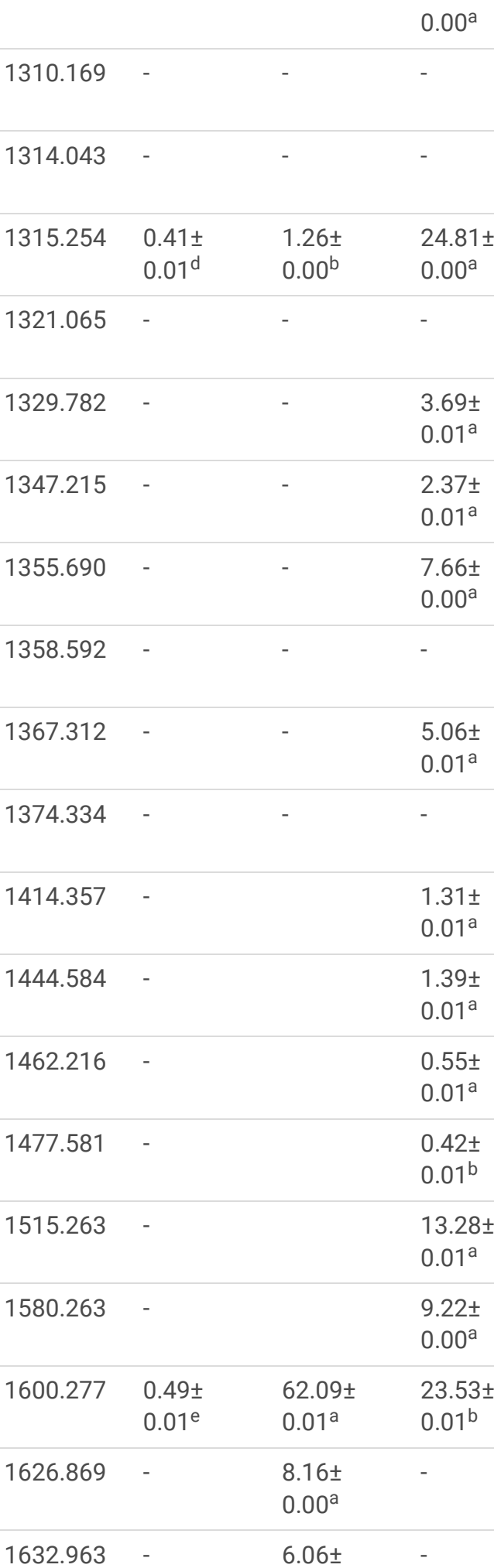

$0.49 \pm$
$0.01^{\mathrm{e}}$

$1626.869-$

$-$

(1)

$632.963-6.06 \pm$

$$
0.00^{\mathrm{a}}
$$

1692.337

$0.87 \pm$
$0.00^{\mathrm{a}}$

$\begin{array}{lll}0.71 \pm & \mathrm{C}_{10} \mathrm{H}_{10} \mathrm{O}_{2} \\ 0.00^{\mathrm{a}} & & \end{array}$

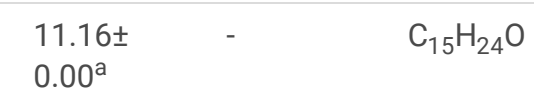

$-\frac{1}{2}$

$\begin{array}{ll}\begin{array}{ll}1.24 \pm \\ 0.00^{\mathrm{C}}\end{array} & \mathrm{C}_{15} \mathrm{H}_{24} \mathrm{O} \\ - & \mathrm{C}_{15} \mathrm{H}_{26} \mathrm{O}\end{array}$

\section{$2.26 \pm$ \\ $0.01^{a}$}

$\begin{array}{llll}3.69 \pm & - & - & \mathrm{C}_{15} \mathrm{H}_{24} \mathrm{O} \\ 0.01^{\mathrm{a}} & & & \end{array}$

$2.37 \pm$
$0.01^{\mathrm{a}}$

$\begin{array}{llll}7.66 \pm & 3.25 \pm & - & \mathrm{C}_{15} \mathrm{H}_{26} \mathrm{O} \\ 0.00^{\mathrm{a}} & 0.01^{\mathrm{b}} & & \end{array}$


\#Retention indices (RIs) relative to n-alkanes (C6-C40) on the same methyl silicone capillary column. Values with different letters are statistically different (Duncan, $\mathrm{p} \leq 0.01$ ).

Table 4. Analysis of variance of species effect on Inhibition zone of essential oil of five Lamiaceae species against some microorganisms

\begin{tabular}{lllll} 
Source of & df & MS & & \\
\cline { 3 - 5 } variation & & B. subtilis & S. epidermidis & S. aureus \\
species & 4 & $16.067^{* *}$ & $9.767^{* *}$ & $583.917 * *$ \\
\hline Error & 10 & 0.067 & 0.067 & 0.183
\end{tabular}

**: $1 \%$ level of probability is significant

Table 5. Inhibition-zone diameters of EOs from five Lamiaceae species and referent antibiotics

\begin{tabular}{|c|c|c|c|c|c|c|c|c|}
\hline \multirow{3}{*}{$\begin{array}{l}\text { Test } \\
\text { microorganisms }\end{array}$} & \multicolumn{8}{|l|}{ IZ (mm) } \\
\hline & \multicolumn{5}{|l|}{ EOs } & \multicolumn{3}{|l|}{ Antibiotics } \\
\hline & TDEO & NSEO & HIEO & SIEO & ROEO & Rifampin & Gentamicin & Nystatin \\
\hline Sh. dysenteriae & $16.33 \pm 0.58^{a}$ & ND & ND & ND & ND & 9 & 17 & NA \\
\hline P. aeruginosa & ND & ND & ND & ND & ND & ND & 20 & NA \\
\hline B. subtilis & $14.00 \pm 0.50^{a}$ & $9.00 \pm 0.00^{c}$ & $10.00 \pm 0.00^{b}$ & $9.00 \pm 0.00^{c}$ & $9.00 \pm 0.00^{c}$ & 19 & 30 & NA \\
\hline S. epidermidis & $9.00 \pm 0.00^{b}$ & $9.00 \pm 0.00^{b}$ & $11.00 \pm 0.00^{\mathrm{a}}$ & ND & $9.33 \pm 0.58^{b}$ & 44 & 39 & NA \\
\hline E. coli & $11.33 \pm 0.58^{a}$ & ND & ND & ND & ND & 10 & 23 & NA \\
\hline S. aureus & $39.33 \pm 0.58^{a}$ & $9.67 \pm 0.58^{b}$ & ND & $8.50 \pm 0.50^{c}$ & $9.00 \pm 0.00 \mathrm{bc}$ & 21 & 27 & NA \\
\hline K. pneumonia & $17.67 \pm 0.58^{a}$ & ND & ND & ND & ND & 8 & 17 & NA \\
\hline P. vulgaris & $14.00 \pm 0.50^{a}$ & ND & ND & ND & ND & 8 & 24 & NA \\
\hline S. paratyphi-A & $11.67 \pm 0.58^{a}$ & ND & ND & ND & ND & 8 & 18 & NA \\
\hline C. albicans & $11.67 \pm 0.58^{a}$ & ND & ND & ND & ND & NA & NA & 33 \\
\hline A. sniger & $12.00 \pm 0.00^{a}$ & ND & ND & ND & ND & NA & NA & 27 \\
\hline A. brasiliensis & $25.00 \pm 0.00^{a}$ & ND & ND & ND & ND & NA & NA & 30 \\
\hline
\end{tabular}

IZ: The diameters of the inhibition zones includes the diameters of disks $(6 \mathrm{~mm})$. Values are the means \pm SD of three cultures. Results are expressed as means \pm SD of triplicate values.. NA: no activity, ND: not determined. Values with different letters are statistically different (Duncan, $\mathrm{p} \leq 0.01$ ).

Table 6. Minimal inhibitory concentrations (MIC) of EOs from five Lamiaceae species and referent antibiotics. 


\begin{tabular}{|lllllllll|}
\hline Test microorganisms & \multicolumn{2}{l}{ MIC $(\mu \mathrm{g} / \mathrm{mL})$} & & & & & \\
& & & & & & & \\
& EOs & & & & & & \\
& TDEO & NSEO & HIEO & SIEO & ROEO & Rifampin & Gentamicin & Nystatin \\
\cline { 2 - 9 } & 500 & 125 & 62.50 & 125 & 31.25 & 15.63 & 3.90 & NA \\
\hline P. dysenteriae & 125 & 125 & $15.63>$ & $15.63>$ & $15.63>$ & 31.25 & 7.81 & NA \\
\hline B. subtilis & 125 & 250 & 500 & 125 & 62.50 & 31.25 & 3.90 & NA \\
\hline S. epidermidis & 125 & 250 & 500 & 500 & 62.50 & 1.95 & 1.95 & NA \\
\hline E. coli & 125 & 500 & 250 & 125 & 31.25 & 15.63 & 31.25 & NA \\
\hline S. aureus & 125 & 500 & 500 & $>1000$ & 125 & 31.25 & 1.95 & NA \\
\hline K. pneumonia & 125 & 125 & 62.50 & 125 & 31.25 & 15.63 & 3.90 & NA \\
\hline P. vulgaris & 250 & 250 & 500 & 250 & 62.50 & 15.63 & 15.63 & NA \\
\hline S. paratyphi-A & 125 & 250 & 62.50 & 125 & 62.50 & 15.63 & 3.90 & NA \\
\hline C. albicans & 31.25 & 250 & 62.50 & 500 & 500 & NA & NA & 125 \\
\hline A. sniger & 250 & 2000 & $>2000$ & $>2000$ & 2000 & NA & NA & 31.2 \\
\hline A. brasiliensis & 250 & 2000 & $>2000$ & $>2000$ & 2000 & NA & NA & 31.2 \\
\hline
\end{tabular}

Table 7. Minimal bactericidal/fungicidal (MBC) concentrations of EOs from five Lamiaceae species

\begin{tabular}{|c|c|c|c|c|c|}
\hline \multirow[t]{3}{*}{ Test microorganisms } & \multicolumn{5}{|c|}{$\mathrm{MBC}(\mu \mathrm{g} / \mathrm{mL})$} \\
\hline & \multicolumn{5}{|l|}{ EOs } \\
\hline & TDEO & NSEO & HIEO & SIEO & ROEO \\
\hline Sh. dysenteriae & 500 & 1000 & 62.50 & 1000 & 500 \\
\hline$P$. aeruginosa & 125 & 125 & $15.63>$ & 250 & 62.50 \\
\hline B. subtilis & 125 & $>1000$ & 500 & 250 & 500 \\
\hline S. epidermidis & 125 & 250 & 500 & 500 & 125 \\
\hline E. coli & 125 & 500 & 250 & 500 & 125 \\
\hline S. aureus & 500 & $>1000$ & 500 & $>1000$ & 500 \\
\hline K. pneumonia & 250 & 125 & 62.50 & 1000 & 125 \\
\hline P. vulgaris & 250 & 500 & 500 & 500 & 125 \\
\hline S. paratyphi-A & 125 & 250 & 62.50 & 500 & 125 \\
\hline C. albicans & 62.50 & 250 & 250 & 1000 & 1000 \\
\hline A. sniger & 250 & 2000 & $>2000$ & $>2000$ & 2000 \\
\hline A. brasiliensis & 250 & 2000 & $>2000$ & $>2000$ & 2000 \\
\hline
\end{tabular}

\section{Figures}




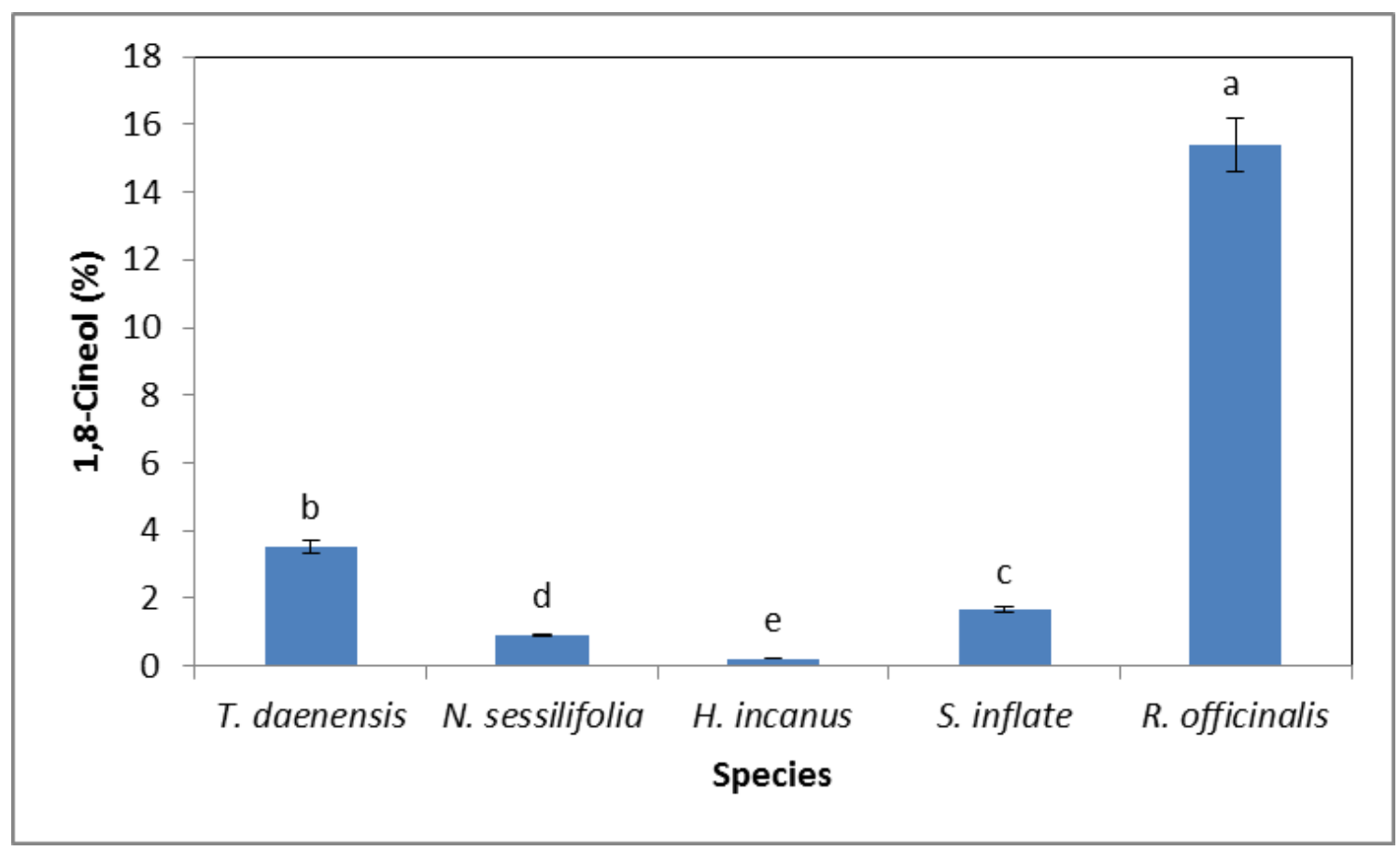

Figure 1

Comparison of the mean effect of species on 1,8-Cineole content of essential oil of five Lamiaceae species

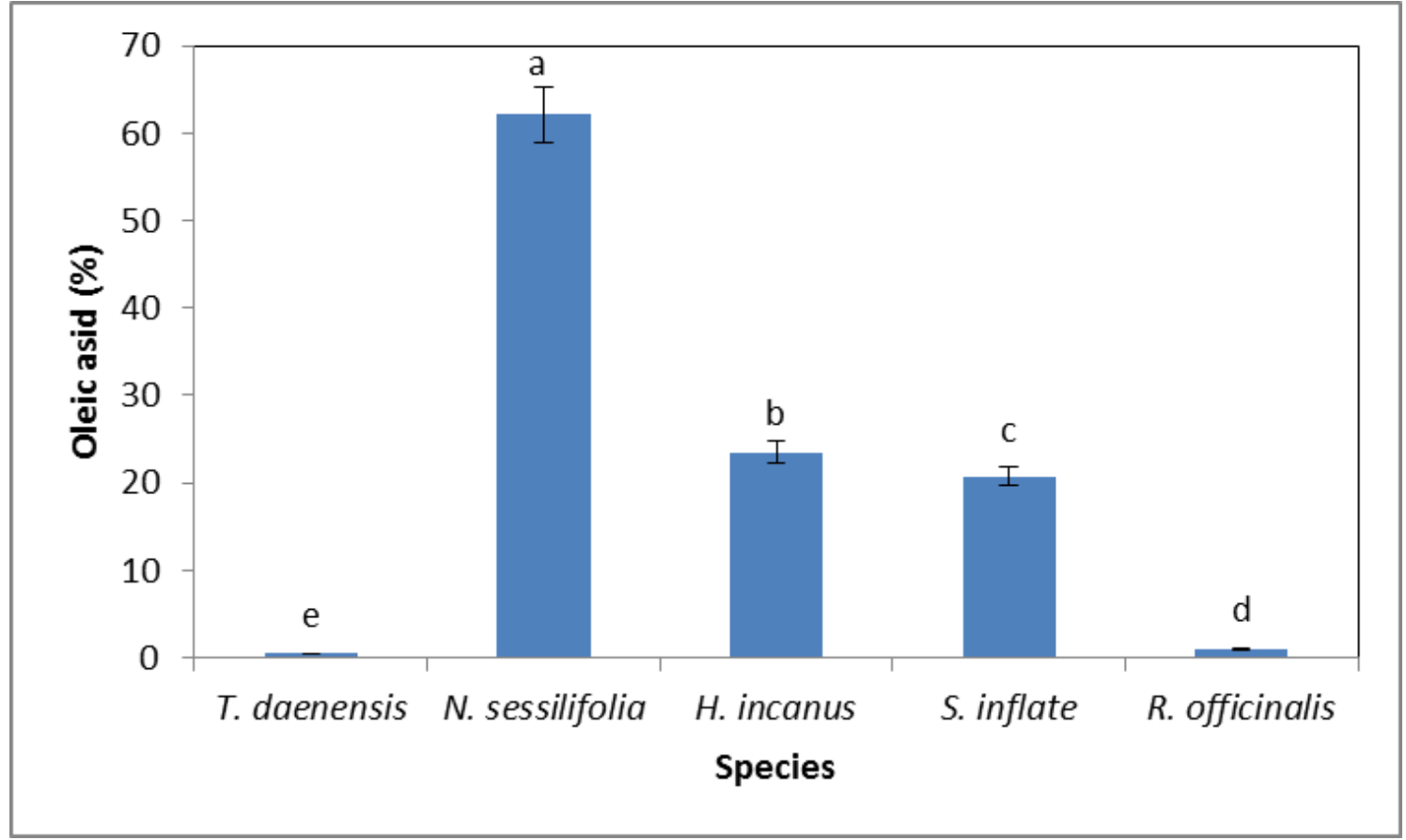

Figure 2

Comparison of the mean effect of species on Oleic acid content of essential oil of five Lamiaceae species 